Historic, archived document

Do not assume content reflects current scientific knowledge, policies, or practices. 


\section{Bud-Selection \\ THE KEY TO \\ BETTER FRUITS \\ Harrison Brothers

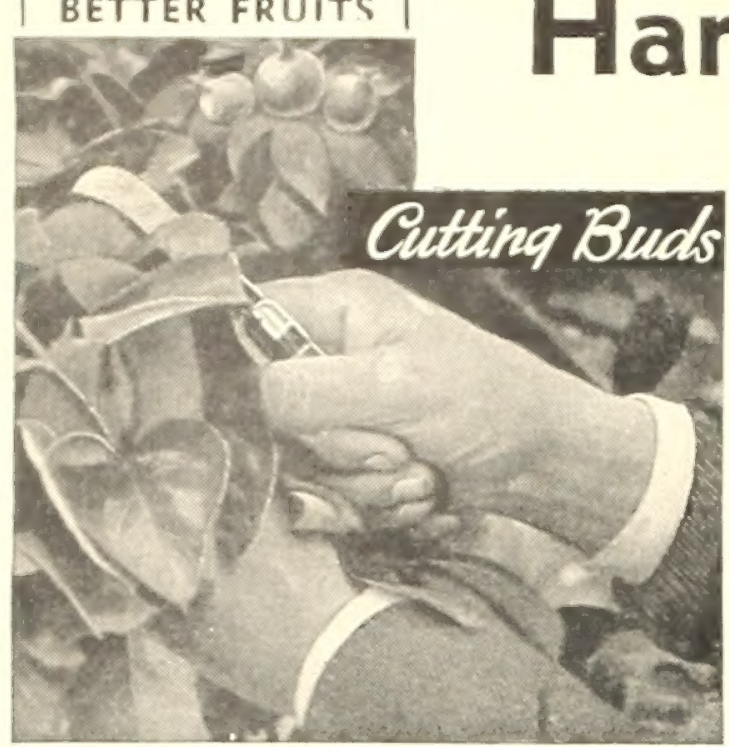

Growers of world famous Fruit Trees, Berry Plants and Ornamentals, cordially invite everyone to visit with us and see how our growing and handling methods result in vastly improved nursery stock. If it is impossible to come here to Berlin, please read this catalog and we believe you will find something to your interest. Remember only the best is sold by Harrisons.

\section{TRUE TO NAME}

The World's Foremost Fruit Variety Identification Specialists Have Examined Harrison-Grown Trees and Pronounced Them True to Name.

Harrisons" "Bud Strains"

In addition to carefully selecting the propagating wood from bearing trees of superior strains, we have also employed the services of the world's most eminent outhorities on tree identification of the Massochusetts Trueness-to-Nome Inspection Service.

To Whom It May Concern:

All of the one- to three-year-old Apple, Plum, and one-year Pear and Sweet Cherry varieties propagated and now growing in the nurseries of Horrison Brothers Nurseries, Berlin, Maryland, have been examined by the Massachusetts Trueness-to-Name Inspection Service. To the best of our knowledge, these trees are true-to-name as they now stand in the nursery row

65 YEARS
LEADERSHIP THANKS-Harrison Brothers OVER 4000
ACRES

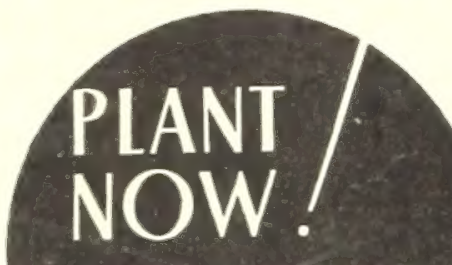

TREES SHRUBS

FRUITS indROSES

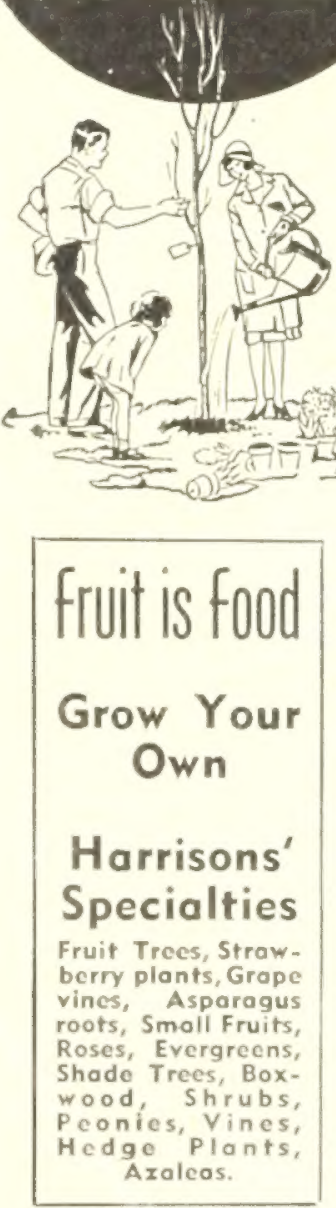

Buying Fruit Trees is an Act of Confidence

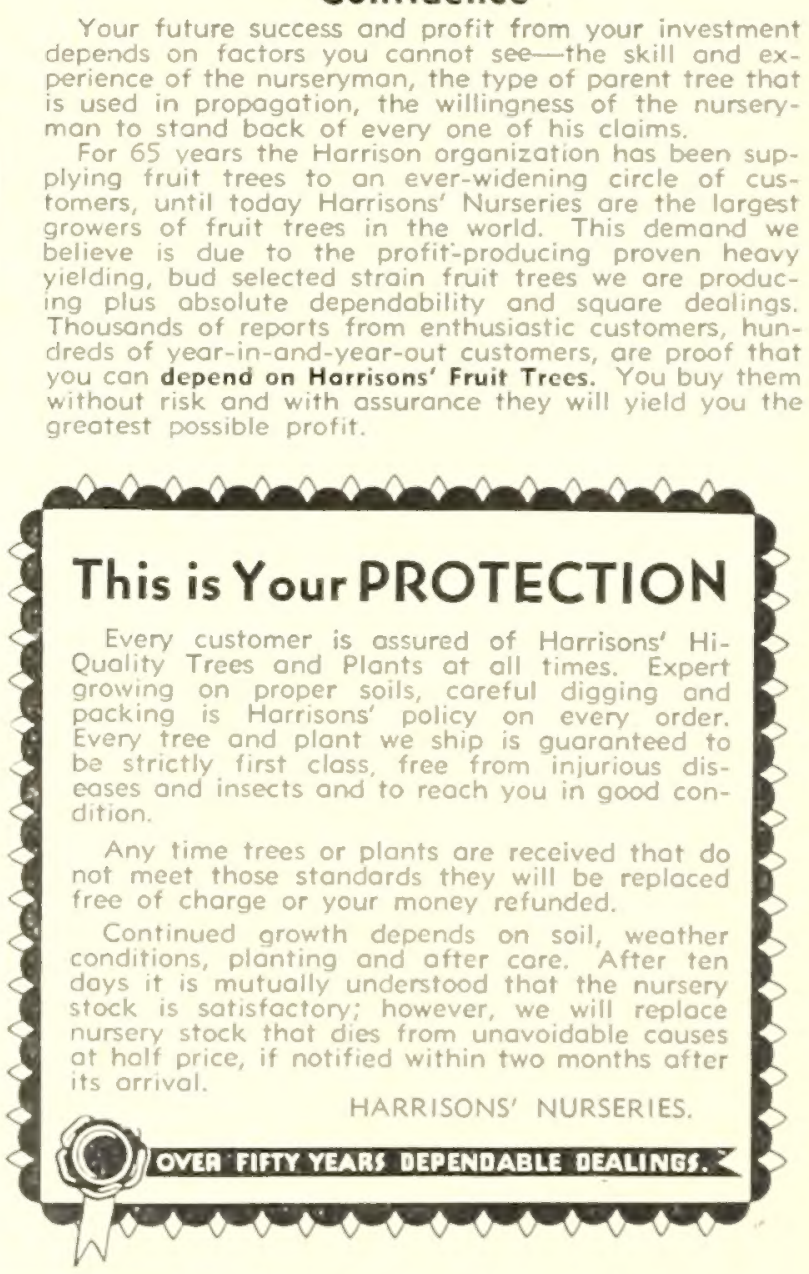

Dependable Nurserymen Propagate From Bearing Orchards
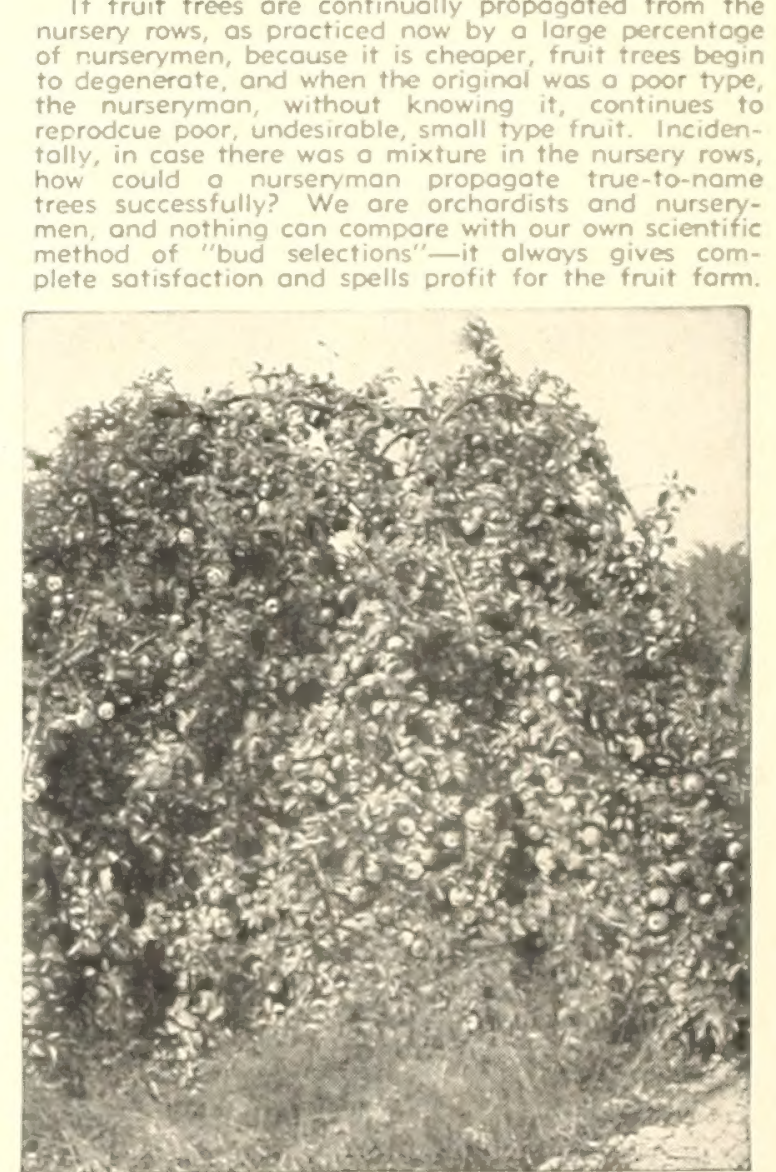

TUUYY HRUIT GROWING is moking inroods on the big farms-little orchords lead the woy to a profitable and worth-while fruit market.

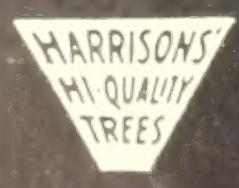

PLANT HARRISONS' SUPER-STRAIN SELECTED TREES GROWN AT BERLIN, MARYLAND

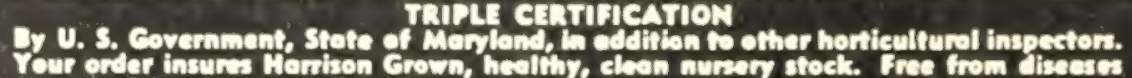
and insect pests. Cenificents of Inspection eceompanies cech shipment. 


\section{NEW BRIGHTER}

Bear Giant Size, Rich Colored, Fine

A HORTICULTURAL TRIUMPH-UNEXCELLED FO

\section{TRIPLE RED DELICIOUS-THE BEST}

King of All Red Apples

Solid bright red color month earlier than the original Red Delicious. Has oll the fine qualities of fomous parent strain. Plant Harrisons' Triple Red Delicious to insure your future finoncial income.

\section{AMERICA'S HIGHEST PRICE APPLE \\ EXCELLENT FLAYOR}

Glorified Red Apple of the World

Ideal for Home Orehards Harrisons' Triple-Red Delicious is not only a commerciol Apple, but it is every bit os well odopted to the home grounds. Whether you wish to plont o thousond or if you have room for only one tree, HarFisons' Triple-Red Delicious will give full value.

Budded

Apple

Trees

TRIPLE RED DELILI____rinest Flavored, Best of All are For

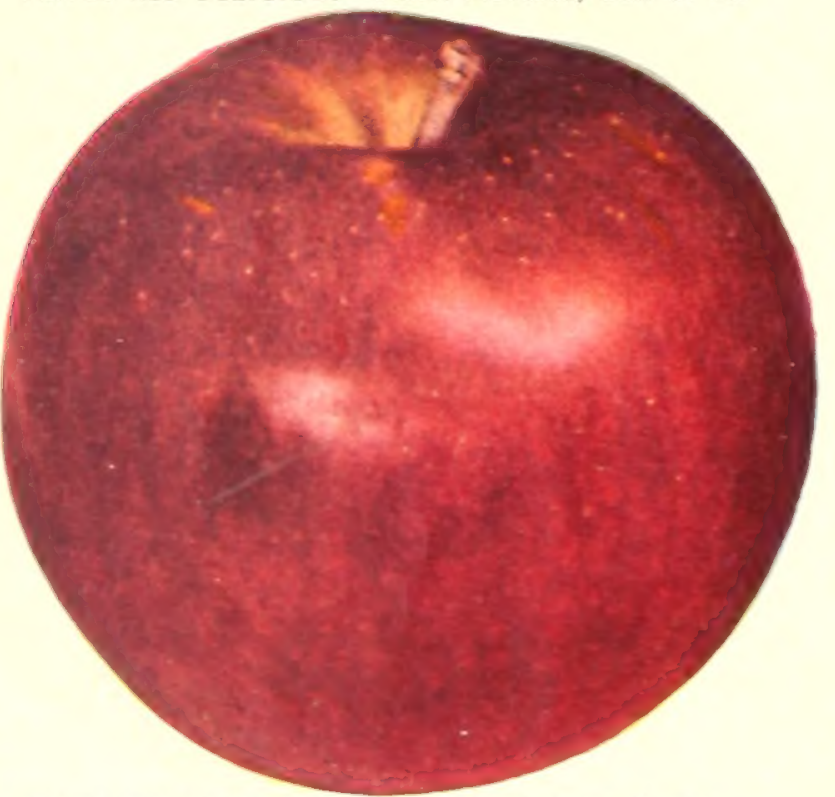

Superior

to

Grofted

Apple

1. Super Colored Bud Sports from the Standard Varieties.

2. Some as Parent in Flavor, Quolity, Productiveness.

3. Color Weeks Eorlier.

4. Produce Highest Percentage Foncy Fruit.

5. Tests Show They Come Into Beoring Sooner.

6. Better Shipping and Storage Qualities.

7. Completely Tested.

8. Excelled by No Other Red Bud Sports or Strains.

9. No Increases in Price Over Standard Varieties.

10. Greatest Profits.

Trees

\section{SCARLET RED \\ STAYMAN BRILLIANT COLOR}

We offer to the public the great est strain of Stayman Winesap ever discovered. It is a true bud sport found in a Stayman Winesap orchard. Scarlet Red Stayman takes on bright red color weeks eorlier than ordinary Stayman. Its ripening date is the same but can be picked earlier if desired.

A Ready Morket at Top Prices Scorlet Red Staymon is the best generol purpose Apple for planting in the Eost. Its solid scarlet-red color and its bright attrective finish couses it to command highest morket prices. The fruit is large and it produces bumper crops each

FOR JUMBO APPLE TREES SEE PAGE 17

\section{Sipe}

upenian to all Other Tested

\section{Strains}

PLANT BIG TREES for QUICKEST and BEST RESULTS

\section{SOLID RED WINESAP}

Old Winesop generally has plenty of color when planted in most sections, but for those growers who want a mare solid redcolored Winesap, we recommend our new stroin.

THE APPALACHIAN WINNER RED YORKING

(U. S. Plant Potent No, 125

The Red Yorking is o "bud sport" being a mutation of the famous York Imperial. This "bud sport" originated on a tree, grown with other York lmperiol trees, in Harrisons' Nurseries and later sold to Mr. W. H. Allison, near Shippensburg, Penno. for use in plonting a large orchard about 40 years ago.

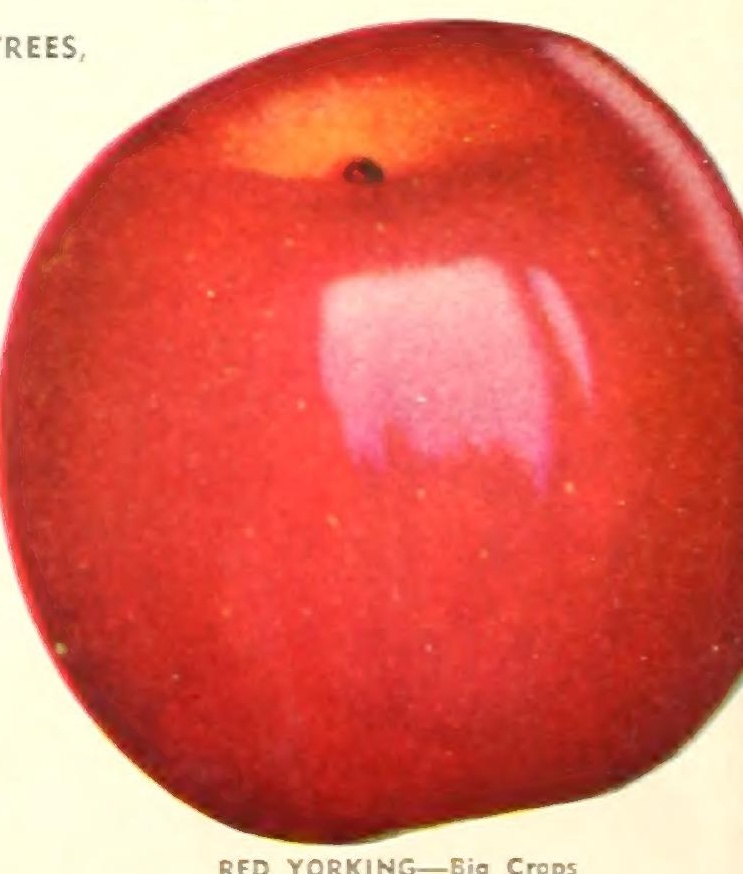




\section{RED VARIETIES}

Alavared Apples

HOME OR COMMERCIAL ORCHARDS

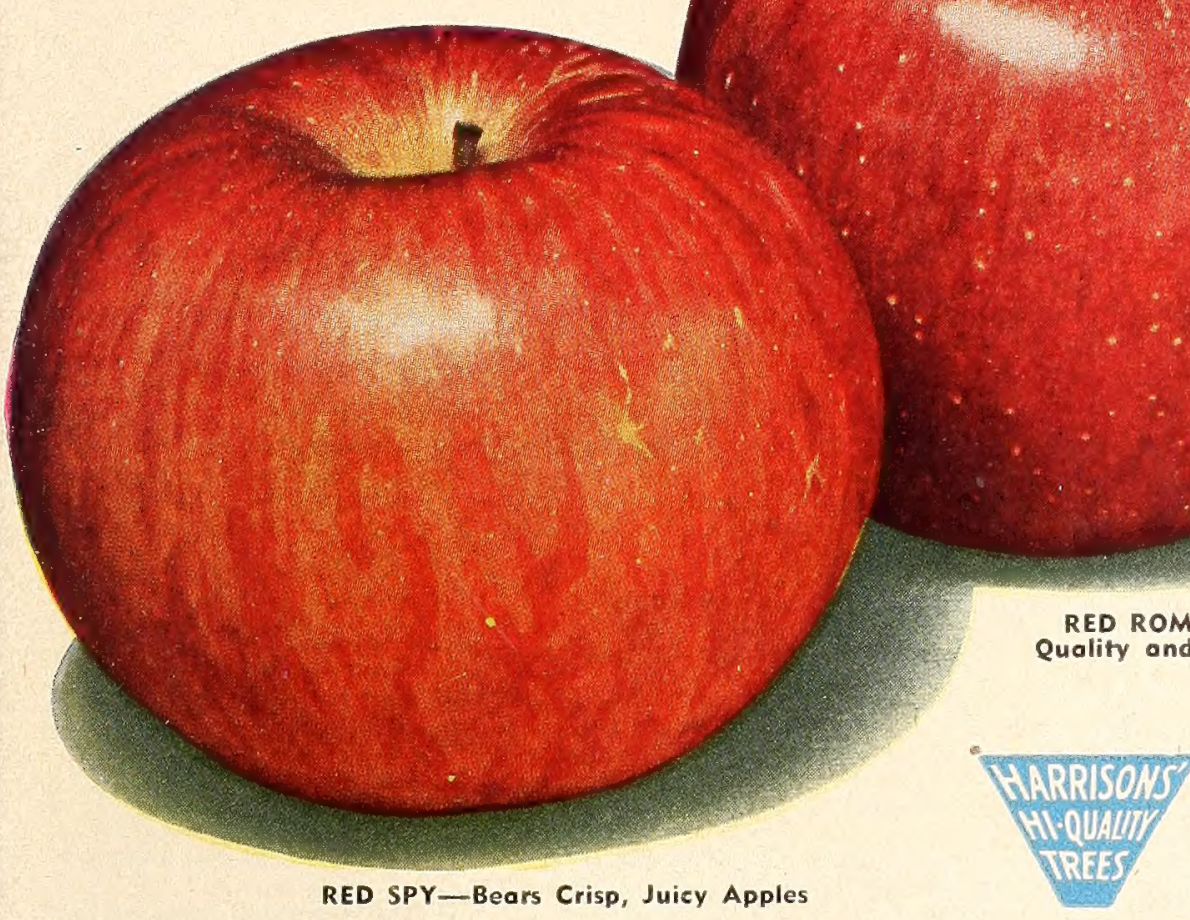

RED ROME BEAUTY

An improved Rome Beauty, identical in vigor and production. Color of fruit much brighter and solid red. Produces much higher percentage of fancy Apples and also superior in quality to the ordinary strain of Rome Beauty. Red Rome Beauty is renowned for bearing at a very early age, producing bumper crops of large size Apples. The tree is a vigorous, strong grower, exceedingly hardy. Pacific Coast strain.

\section{GET YOUR ORCHARD STARTED THIS YEAR}

\section{SUPER RED MCINTOSH}

A new strain of Mclntosh Red that starts coloring earlier and produces a larger percentage of extra fancy fruits. Super-Red Mclntosh, when allowed to mature on the trees, is slightly darker in color than our regular improved Mclntosh Red. Has all the best qualities of ordinary Mclntosh and will mean lorger profits for growers who have been unable to get sufficient color. Mclntosh has been the favorite in the North; this new strain extends the planting area farther South. The most highly colored solid red strain available, regardless of price. We have some exceptionally good one-year trees and fine two-year trees to offer this season. Plant Mclntosh strain of Apples for big profits, equally as good in home orchards as it is commercially.

\section{RED SPY}

A new "bud sport" from New England. Identical with the ordinary Northern Spy in fruiting habit. Extra large size fruit, strong, vigorous, hardy trees. Comes into bearing earlier than the ordinan strain. Colors early, nearly every Apple being solid red in color. We recommend it for commercial and home plantings in northern states.

\section{BRIGHT RED JONATHAN}

We searched the country over to find a strain of Jonathan that had more color than our selected Big Yield Strain of Jonathan. After thousands of miles of travel inspecting all of the new strains of this famous variety we found the one we had been looking for. It colors solid red several days earlier otherwise it is identical with ordinary Jonathan. Growers who want more, deeper colored apples will find our Bright Red Jonathan the best colored strain obtainable.

\section{RED GRAVENSTEIN}

Here is the Apple that has been overlooked by eastern growers. Old-fashioned Gravensteins have been grown in tremendous volume during the past twenty-five years, mostly in California, a few in the Eastern States. The old strain lacks the color to make it sell. Our new Red Gravenstein colors a solid bright red long before it is ripe. The quality of Red Gravenstein is extra good for an early Apple and its ability to carry to distant markets, even after it gets solid red makes it command the highest prices.
SUPER RED MCINTOSH Superb Flavor

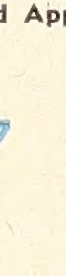

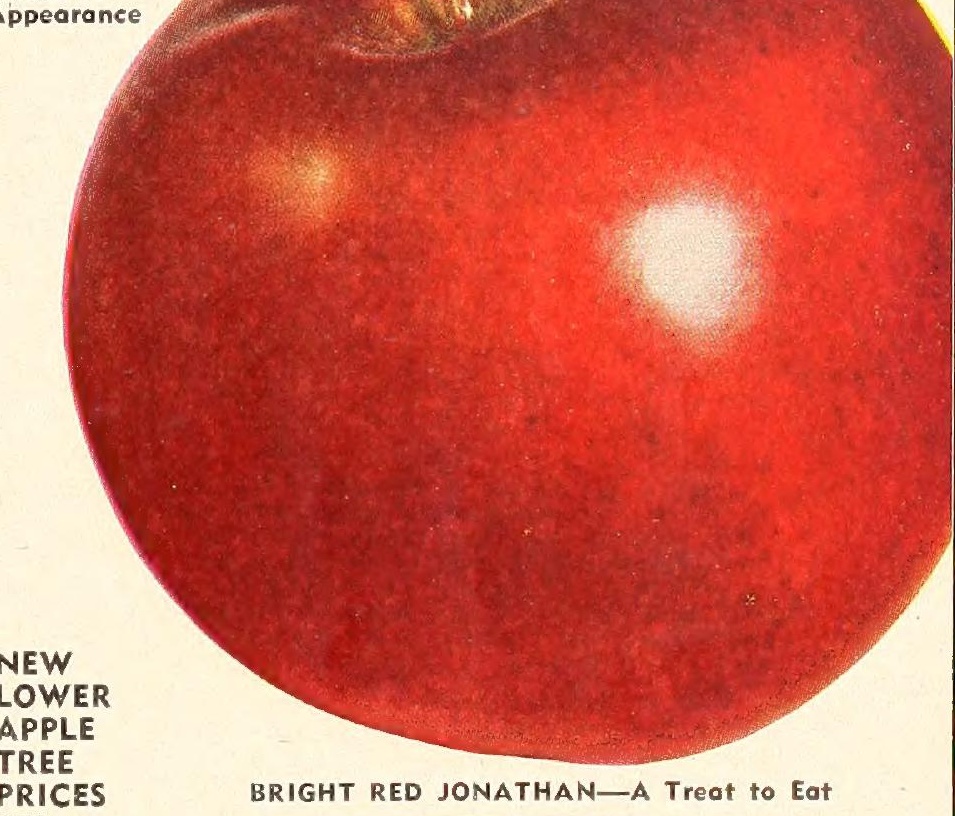

SEE

PAGE 3

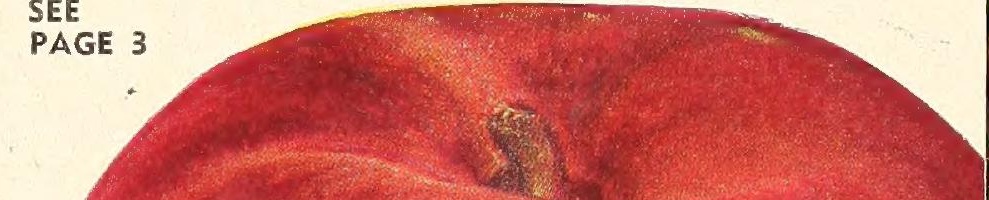




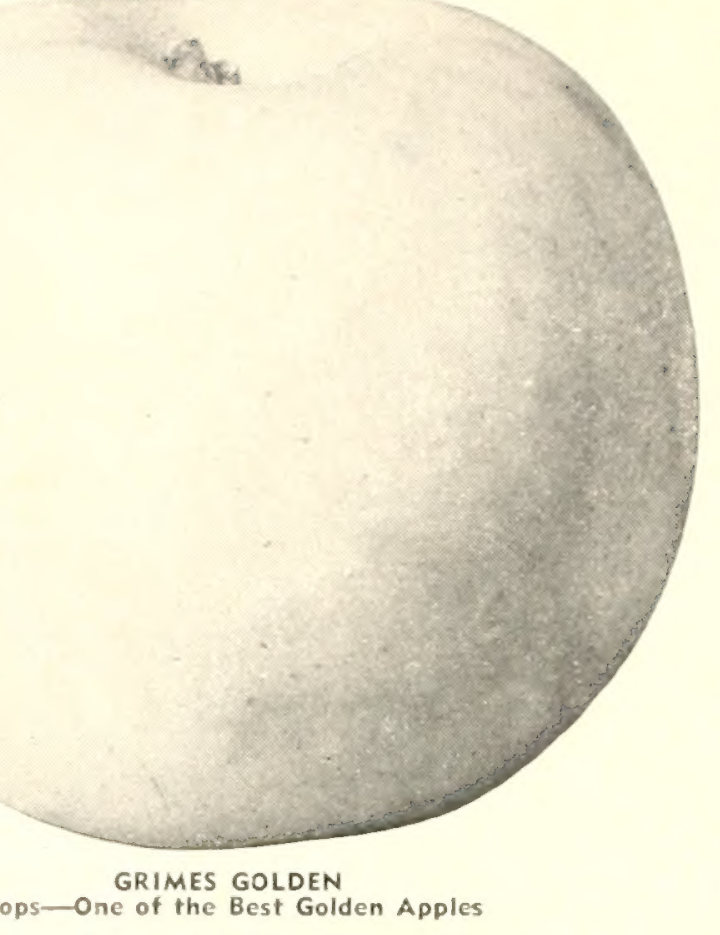

Harrisons' Maryland Grown Apple Trees are the Finest Quality in the World
Harrisons" Selected "Big Yield" Strain-Best Home Orchard Apple medium sized, golden yellow, tender, rich, oromatic, sub-ocid delieious, a known, and a good keeper. No better variety

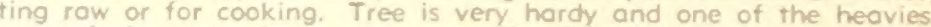

\section{YELLOW DELICIOUS It's Golden!}

\author{
A Prolific Cropper at an Early Age

\section{DELICIOUS}

Sometimes Called Stark Delicious - This is the Original Strain of Red Delicious Of peculior and distinctive shope; brilliant dark red, flesh fine grained, juicy,

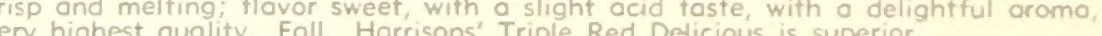

\section{McINTOSH RED}

Improved Type-Heavy Yielding Strain Preferred by Many Growers in the North. Until the discovery of our New Super Red Mclntosh our improved Mclntosh Red was the best strain of Mclntosh avollable. It colors solid red when climatic and he condin a dis it to remain on the trees until it is mature. This heavy yieldhin strain is much superior to any strain of Mcintosh, especiolly the dul striped planting this time not have trouble getting sufficient color then we recommend you produces bumper crops each year. Generally considered as the best flavored Apple Recommended for home or commercial orchard plantings.

\section{OTHER GOOD APPLES}

STAYMAN WINESAP

Big Yield Stroin Stoym ofter year th colors to good bright red and gets nearly solid red colored when allowed to stay on trees until fully ripe. This is an improved strain and is preferred by many growers in the East. Tested and time-proven by thousands of growers.

SMOKEHOUSE. Large Apples of superfine flavor, excellent for eating, yellowish green motfled with dull red and with many russet dots; flesh
firm, crisp, juicy and oromatic. Tree large, vigorous and reliably profirm, cris

WINESAP An Apple favorite in Virginia. Sometimes called Old smooth and a fine dark and Virginia Winesap. Medium size, oblong, smooth, and a fine dark red-one of the best red colored Apples excellent flavor. Very lang keeper and considered the best cold storage variety, keeping until July. Strong grower; comes into bearing early. Our strain produces bumper crops of the lorger sized Apples YORK IMPERIAL. Medium to large size, round, irregular greenish vel-

derful koeper. Keeps in cold storage until June. Vigorous grower. strong and healthy; on unusually heavy beorer.

MAMMOTH BLACK TWIG (Poragon). Extro large in size and round; skin smooth yellowish eovered with deep red, the general effect being dork red; flesh tender, tinged with yellow, crisp, sub-acid, oromatic, fine flavor, of excellent quality, long keeper of great value. An im NORTHERN SPY. Large, bright scarlet-red, with yellow markings. Flesh erect grower, very healthy, extremely hardy and a free producer. We exceptionolly heavy bearing stroin that comes into bearing NORTHWESTERN GREENING.

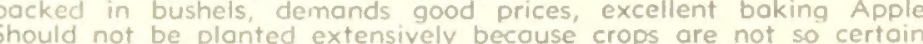
due to blossoming early. Trees are extremely hardy, vigorous, and RHODE ISLAND GREENING. The Popular Northern Apple. Large, greenbarrel Apple, An excellent keeper, a popular preserving, con-
DOUBLE RED BALDWIN. A new dress for this old reliable variety. Solid it sell better. This new strain will bring

CORTLAND. A new variety resulting from cross pollenization of Mc Intosh Red and Ben Dovis, and inheriting the good qualities of each parent. Beautiful red Apple, approximately the same size and fine

GALLIA BEAUTY. A Rome Beculty type of Apple identical in every respect, except its earlier coloring qualities; recommended for com-
mercial planting. Harrisons' have the genuine original strain of Gollio Beouty.

BALDWIN. Large, red, yields big crops; good keeper. Winter. JONATHAN. Medium to large, red, juicy. Good keeper and on excellent LOWRY. Beoutiful mahogony-red, good, medium size, round oval shape, hearly sweet, mild sub-acid; excellent flavor, good shipper, long kets. New populor commercial variety in Virginic.

\section{CRAB APPLES}

Priced on poge 3 ouble Purpose-An OrnoCombined. HYSLOP. Deep crim-
son, lorge size sub-acid and of good quality. Fine for all kinds of good to eat fresh.

NEW LOWER APPLE TREE PRICES

SEE

Page 3

JUMBO

SI'ZE

PAGE 17

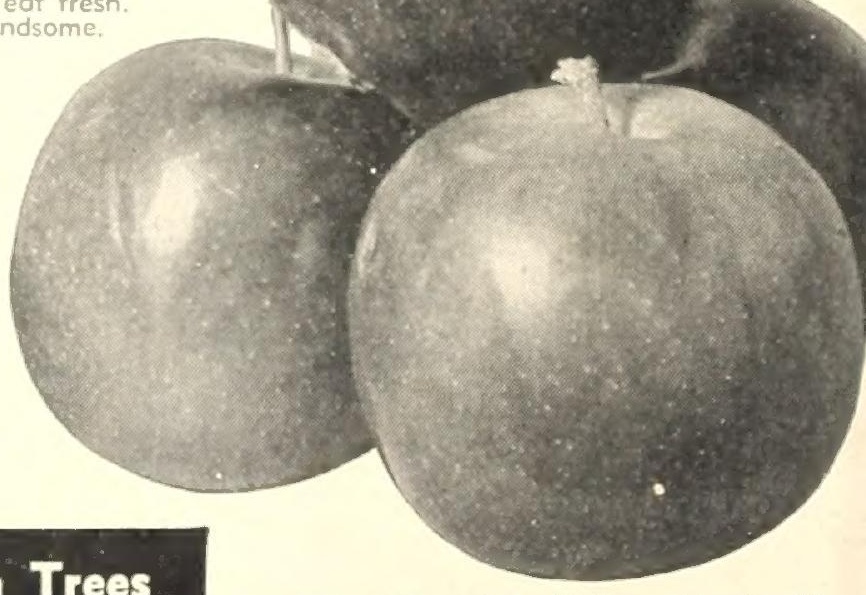

TRANSCENDENT. Yellow striped with for preserving. Best of all Crab APples. Tree lorge; quick grower. 


\section{HERE'S A "LOAD" OF REASONS WHY HARRISONS' PEACH TREES ARE BETTER}

A-Our organization has over 65 years' experience.

B-Every step in growing under the personal supervision of the Harrison Brothers.

C-One hundred and fifty thousand trees in Harrison Brothers orchards from which our propagating trees are selected.

D-Use of modern methods for planting, cultivating and digging.

E-Over 4,000 acres of various types of soil.

F-Ideal soil and climatic conditions.

G-Co-operation with leading horticulturists and experimental stations all over the world.

\section{Very Early Varieties}

DIXIRED. Very early, yellow, cling, medium size, round, bright attractive red blush; good flavor; prolific bearer. Ripens two weeks earlier than Golden Jubilee or about three days later than Red Bird. A new variety originated and introduced by the U. S. Department of Agriculture, Beltsville, Maryland. its most outstanding commercial feature is that it is a good shipper and has been planted extensively in Georgia to meet the demands for the very early Peach market.

DIXIGEM. Early, yellow, semi-freestone, red blush, medium size, good quality. Ripens a few days sooner than Golden Jubilee. A new variety originated and introduced by the U. S. Department of Agriculture, Beltsville, Maryland. Extensively planted in Georgia.

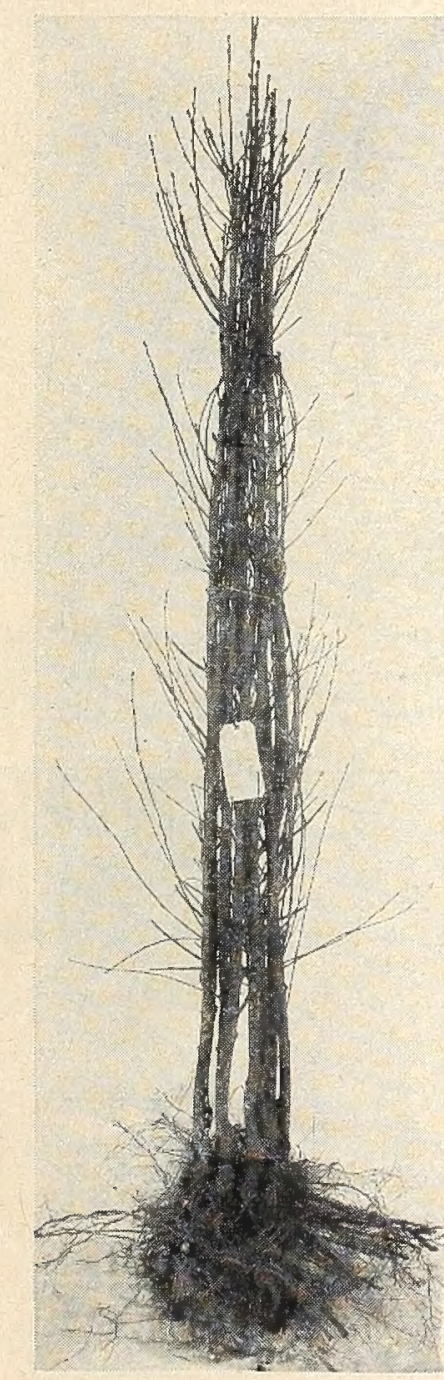

GREENSBORO. White, freestone extra large for such an early Peach. One of the handsomest, being a large, yellowish white with crimson cheek; flesh is white and of average quality. Exceedingly hardy, being an extra heavy, prolific bearer and adapted for wide variations in Peach regions

\section{Plant Large Peach Trees far 2uickest and Best Results}

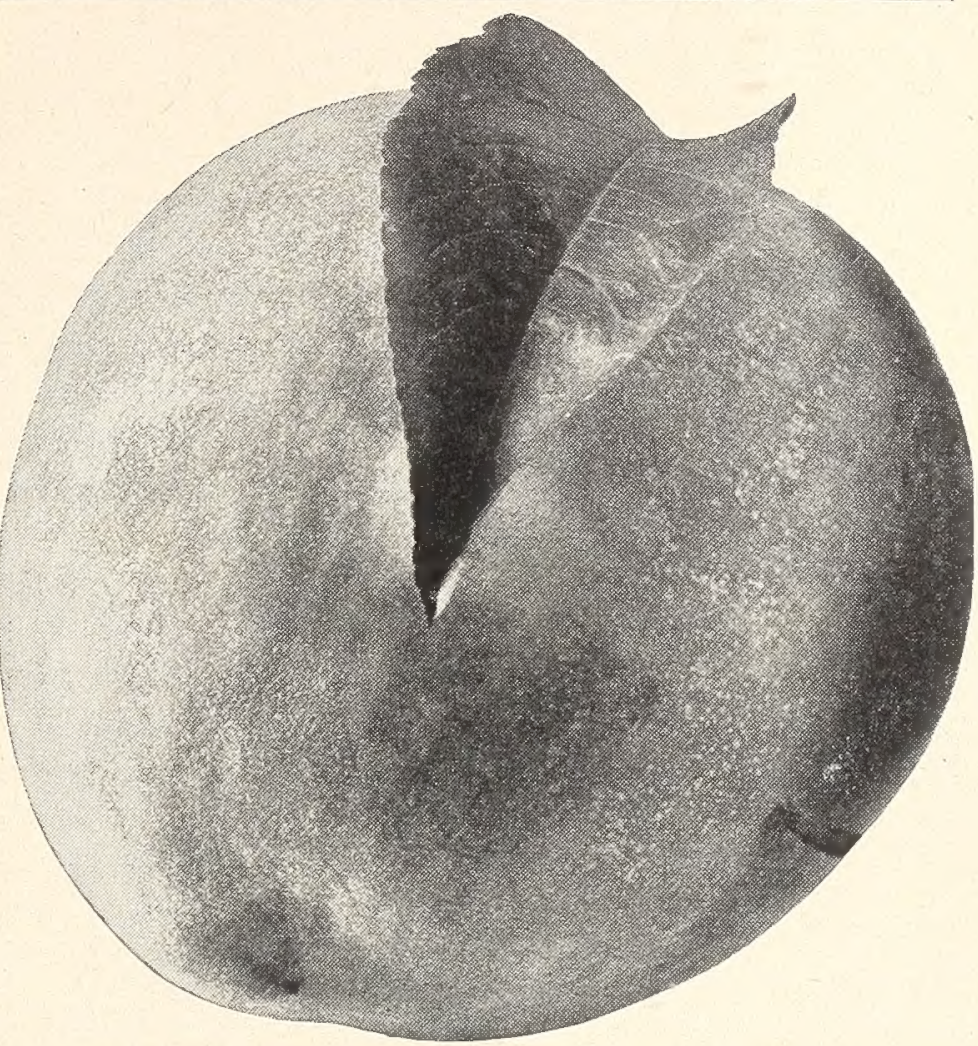

RED BIRD-Earliest Large Peach, Commanding High Prices

\section{RED BIRD}

EARLIEST OF ALL PEACHES

Most Popular Extro Early Market Peach

Bright glowing color-" red as fire" —on a background of creamy white.

Handsome. Large-as large as Elberta. Ripens about 45 days before Elberta. Clingstone. Good to eat and fine for pies, cobblers and Peach pickles. Quality good, especially when left on the tree until they get fully ripe

"Break all young-bearing records." "Break all bearing records." "One crop paid for my whole orchard." "Most profit. able early Peach." "Sell fast as can ship." "Better shipper than Elberta."

JUNE ELBERTA. A big, handsome red and gold Peach, highly colored, excellent quality and a dandy home Peach, being a new variety. One of the earliest of the good yellow-fleshed Peaches, this semi-freestone variety quickly returns cash dividends before later varieties reach the market.

\section{HARRISONS' HARDY PEACH TREES}

\section{We absolutely guarantee Harrison-grown Peach trees,} variety for variety, to be as hardy or hardier than trees grown in any locality north of us.
One-Year, Budded, 4- to 5-Ft. Ideal Planting Size

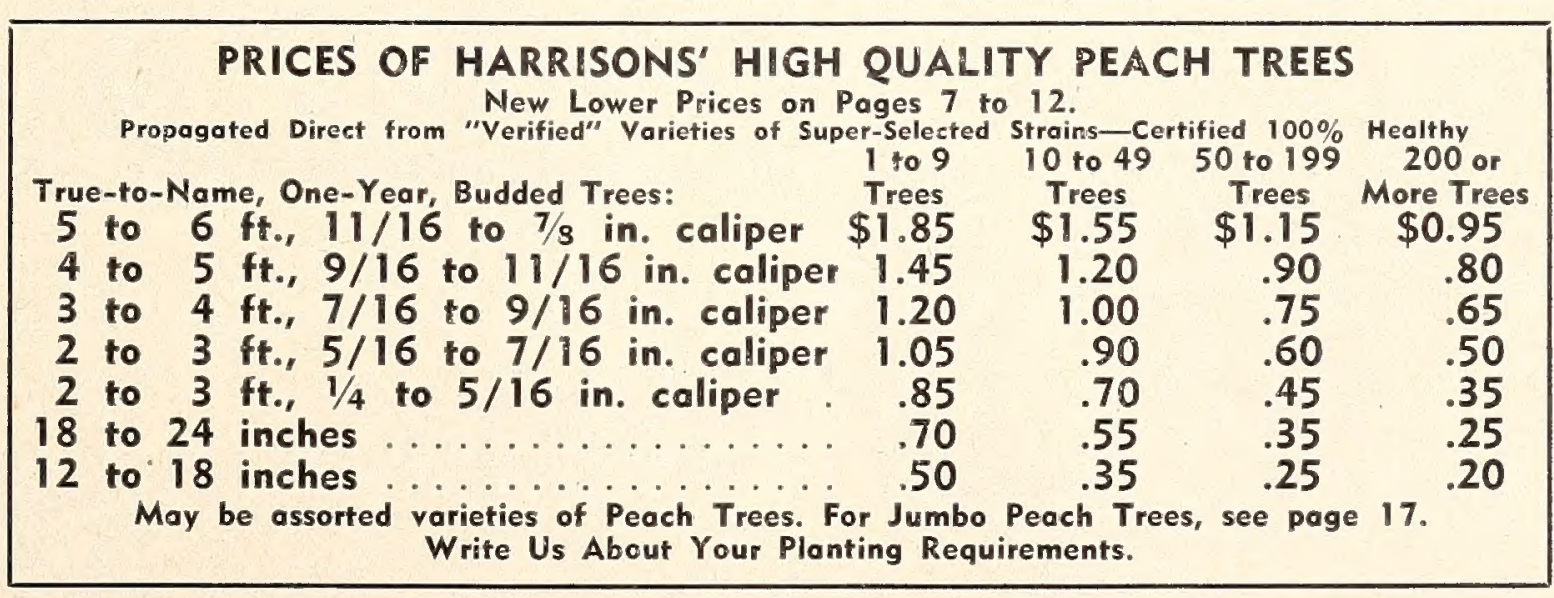

HARRISON-A Name in Trees You Can Trust 


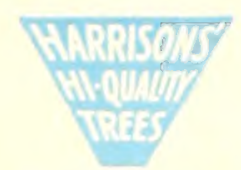

REDHAYEN

PEACH

They Taste

rhey Look 


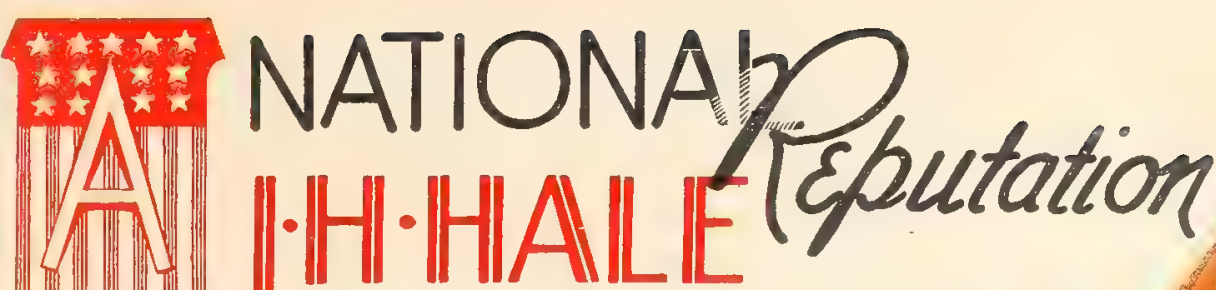

Originated by the late PEACH KING MIDSEASON-Ripens 2 to 3 days before Elberta.

\section{Original Strain} J. H. HALE

Our "Hales" are propagated direct from the original strain, the variety originated by the late J. H. Hale of 'South Glastonbury, Connecticut and Fort Valley, Georgia, known as the Peach King of America. There are many types and strains of J. H. Hale grown, but the only one worthy of commercial importance is the original strain, which is the extra large, round, highly colored Peach. The original strain necessitates cross-pollination and it is necessary, for proper results, to plant a few Belle of Georgia or Elberta or Hiley or any other variety of Peaches along with Hale for cross-pollenization.

\section{Extra Large Size Yellow, freestone, extra large, beau-} Extra Larged coloring, firm and of the highest quality and enticing flavor. J. H. Hale ripens about two or three days prior to Elberta. Prices on pages 7 and 11 . Jumbo size, page 17 .

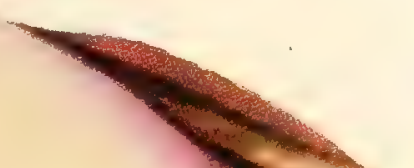

BELLE OF

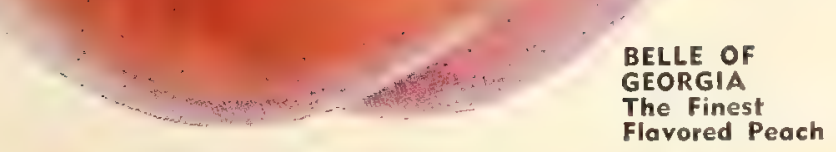

\section{SULLIVAN EARLY ELBERTA}

An Early Ripening Red Bud Sport of Elberta MIDSEASON YELLOW-FREESTONE

Here is the early ripening strain of original Elberta growers have been wanting. Discovered by $\mathrm{Mr}$. Sullivan in a Georgia orchard. Identical to Genuine Elberta in every characteristic except it ripens about seven days earlier. Yellow freestone, firm, juicy, rich, good flavored. Equally attractive as Elberta and is a good keeper. Good for either home or commercial planting.

\section{OUTSTANDING REASONS FOR} PLANTING SULLIVAN EARLY ELBERTA

1-Size: Large to Extra Large.

2-Yellow Freestone.

3-Rich, Sweet Flavor.

4-Brilliant Red Colored with Golden Yellow Background. Excellent Long Distance Shipper.

5-Tree Vigorous Grower.

6-Bears Large Crops Annually.

7-Colors a Week Earlier Than Elberta.

8 -Ripens Slowly After Being Picked.

9-Brings Highest Market Prices.

10 -Completely Tested.

\section{Harrisons" \\ Maryland}

Grown Peach

Trees are the

Finest

Quality in

World

SULLIVAN EARLY

ELBERTA PEACH

The Best New

Midseason Yariety
- Fruit Large

- Delicious Flavor

- Attractive

- Big Crops

- Very Hardy

- Easy to Grow

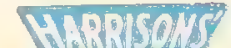
Wriangy 


\section{Harrisons' Peaches ARE A COLLECTION OF THE WORLD'S BEST}

\section{TRIOGEM}

Developed by the Master Plant Biceders of New Jersey MEDIUM TO LARGE, FIRM, ATTRACTIVE

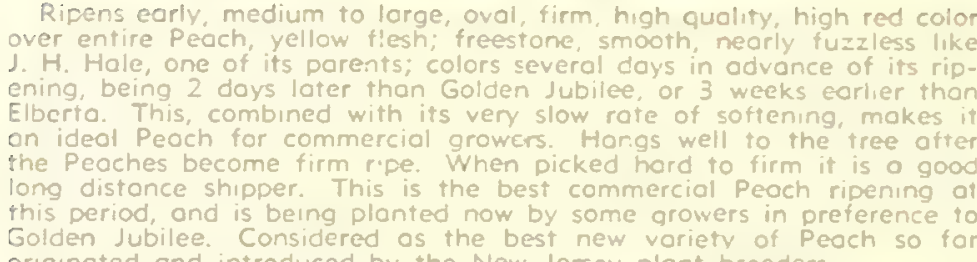

A REAL PROFIT MAKER

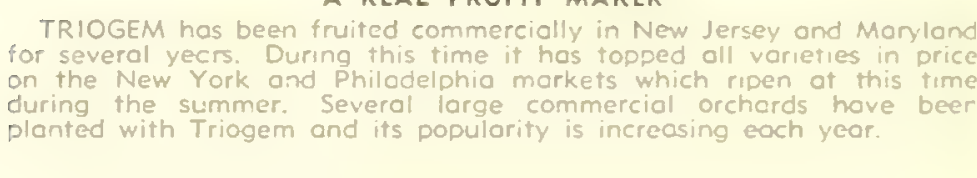

CHAMPION. A Good Home Peach.

factor

Peoch it

ROCHESTER

oit, very good the prific beorer. One of the best eorly midseoson yellow freestone pecches for neaby morkets, and highly desirable for conning.

VEDETTE. Early vellow freestone. Globular; large; good red color; good Adepted to Southern os well os Conodion SUNHIGH.

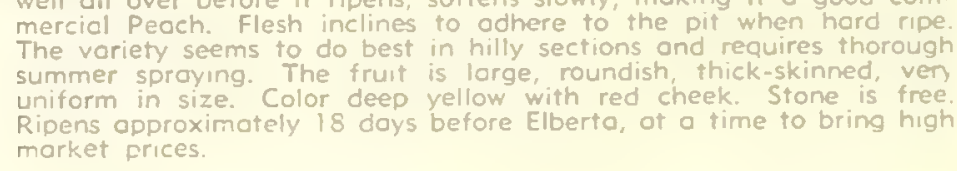

HILEY

Peach

beor her

SOUTH HAVEN.

VALIANT.

SUMMERCREST.

GOLDEN EAST.

Early midseason. Very large,

For Greater Profits From

Your Land Plant Trees 


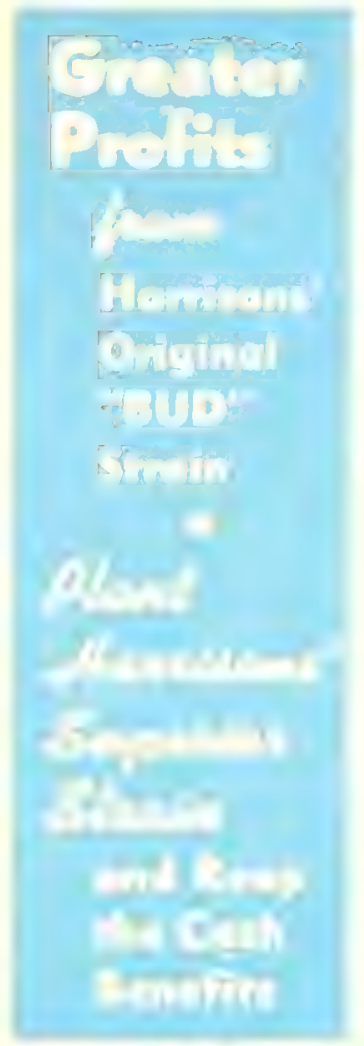

Sare Disappointment-CPlant Only Horrison ORIGINAL STRAIN Elberta

\section{They Cost No Mor:}

SUMBO SIZE TREES PAGE 17.
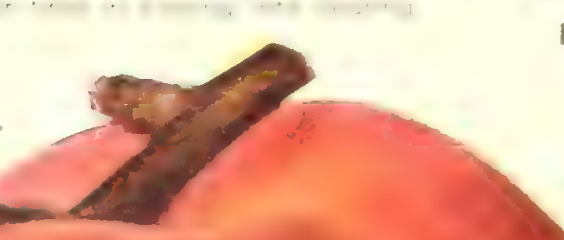
FOR NEW LOWER PEACH TREE PRICES SEE PAGE 7 or 11.

\section{Sensational Standard Peach of the World}

It's the Greatest Money Maker

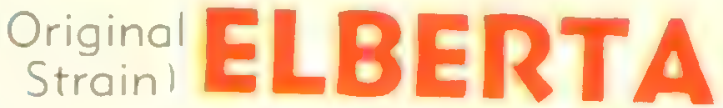
Internationally Famous-The Standard by Which All Other Peaches are Judged

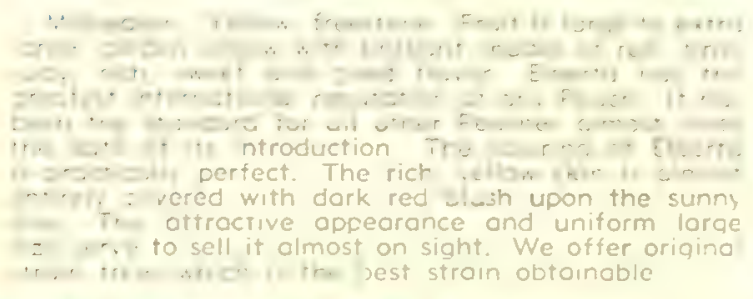
i.
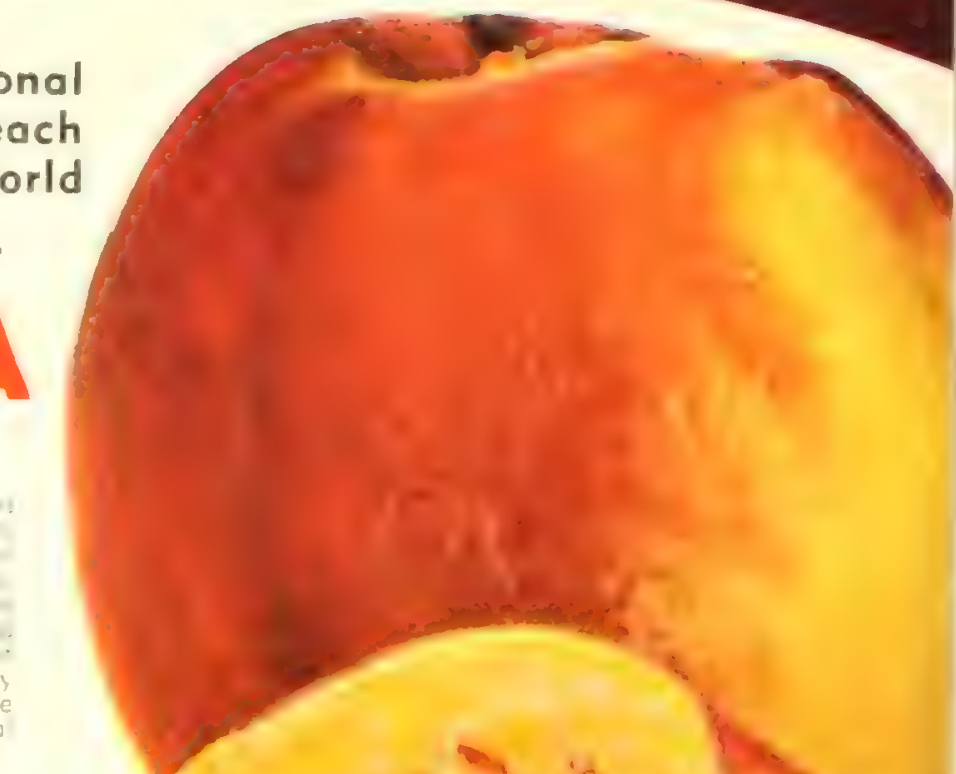
SALES 


\section{New! Exelusive! Sensational!}
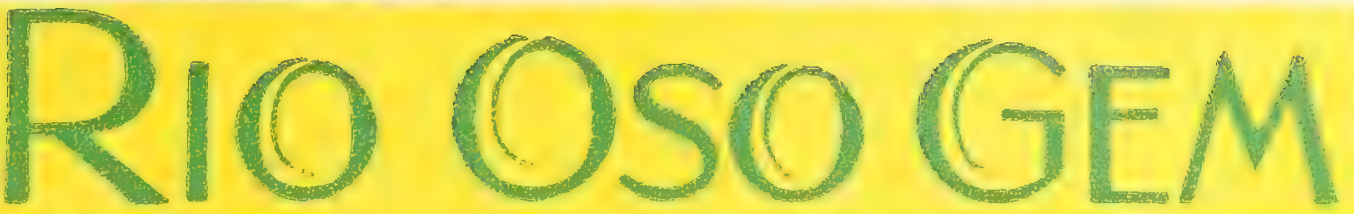

\section{The World's Greatest Peach}

The sensational Peach which has caused the greatest amount of favorable reporis of any Peach introduced in a half century is that marvelous, big Peach, the World's largest, being a pat ented variety, the Rio-Osc-Gem U S Plant Patent No. 84 It has now been fruited in all Peach-growing districts in the United States and Canado and has definitely proven itself to be the best all-around commercial Peach. Ask any man who hos grown the Rio-Oso-Gem.

\section{THE BEAUTIFUL GLORIFIED PEACH}

This beautiful Peach has a brilliant bright red color, running around $95 \%$ good red, whereas they are easy to pack as U. S. Fancy grade. The size of the Peach is all that anyone can expect, as many of these Peaches will run a pound or more in weight and in many instances have been reported that the crop would average three-quarters pound per peach. The flaming, beautiful bright red color in the cheek, al ing reputation as being the prettiest Peach grown.

\section{BEST FIAVORED COMMERCIAL PEACH}

The unexcelled flovor is better thon that of $J$. Hale and Elberta. The enticing flavor makes it a very popular Peoch for fresh eating. The rich flavor is retained when canned or preserved. Now recognized as the leading canning Peach in Californio Rio-Oso-Gem is the only Peach which can be processed by quick freezing and still retain its firm texture, with its beautiful, rich, golden yellow flesh and the same flavor as when picked. We have quick frozen Rio-Oso-Gem Peoches which were picked and processed on September 1, 1944, which are still holding up in excellent condition.

\section{RECORD BREAKER FOR LONG DISTANCE} SHIPMENTS

The Rio Oso Gem is the best of all Peaches for long distance shipments and the fruit will stand up longer after being picked than any other variety of Peach in existence. This stupendous variety adapts itself exceedingly well for shipments in refrig erator cars ore-cooled, under standard refrigeration for transcontinents hauls. This is the greatest Peoch for shipments trucks under ventilation, as its hard, firm texture insures ar rival in excellent condition.

\section{RIO-OSO-GEM}

Ideal for Home Orchards

Ripens 10 days later than Eiberto. Gem is a very prolific bearer and dependable

\section{RIO-OSO-GEM IS NO EXPERIMENT}

Glowing reports have been received from every Peach growing district of the United States and Canada. During the past two years there have been more acres planted to Rio Oso-Gem than any other Peach in California

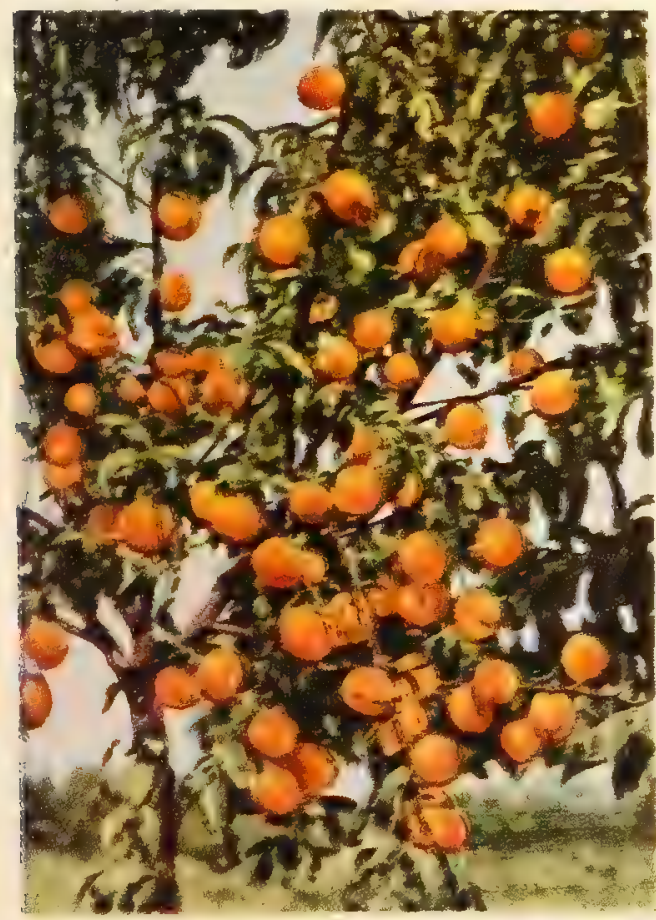

PROLIFIC BEARER-RIO-OSO-GEM PEACH annual cronoe Which is America's largest Peoch orea even exceeding Elberta, the standard Peach of the

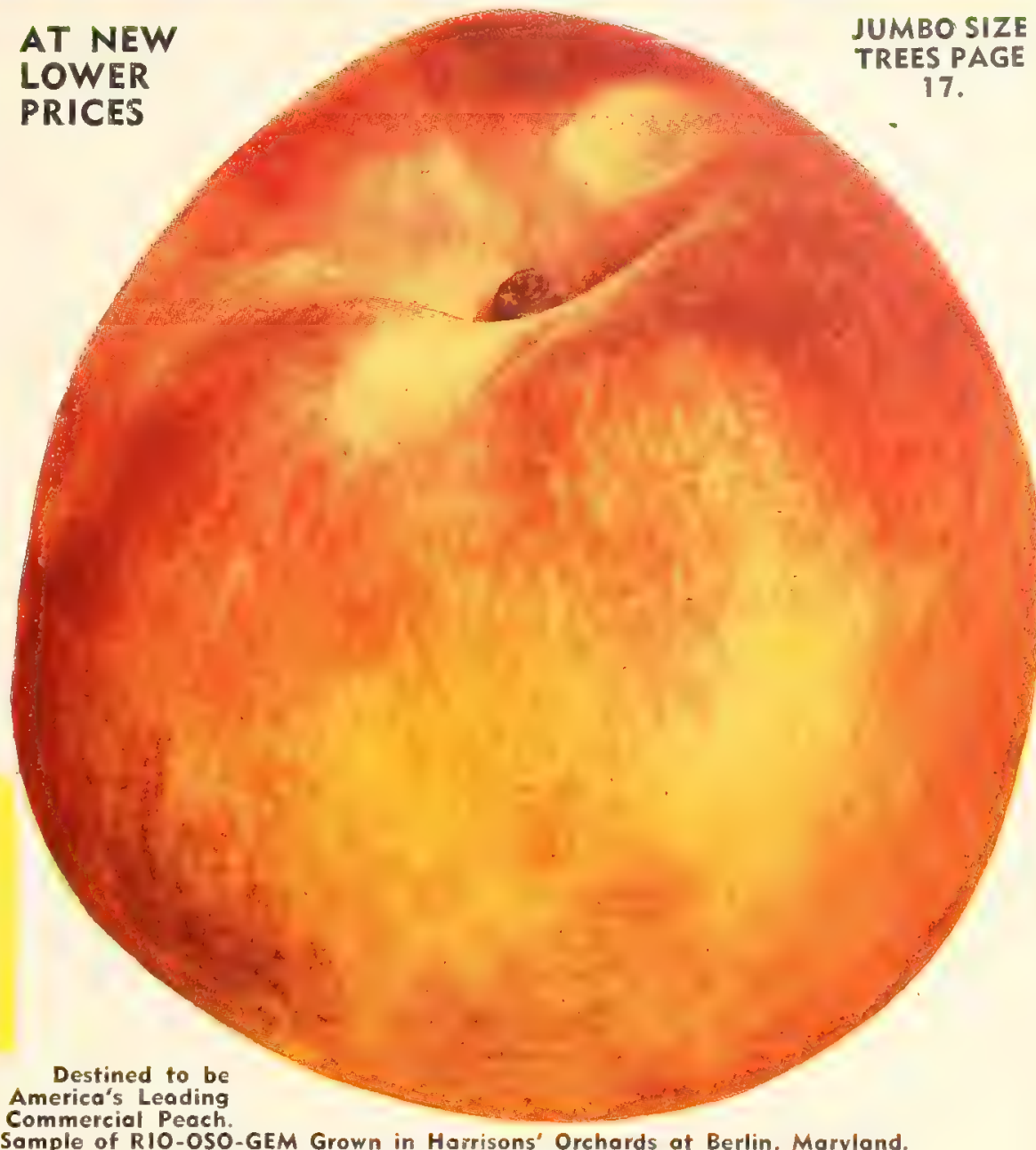

Commercial Peach

Sample of RIO-OSO-GEM Grown in Harrisons Orchards at Berlin, Maryland. Sold only by Horrisons' Nurseries in numerous states.

READ WHAT FELLOW GROWERS SAY
Peach, U. S. Plant Patent No. 84, from all over the United States, some of the typical remarks are from people such as Fussell-Graham-Alderson Company, Forest City, Arkansas: We have
about I,000 of Harrisons "Rio-Oso-Gem Peach trees from which we have been harvesting the largest and prettiest Peaches I ever saw. We sold our Elberta Peaches, U. S. No. I grade at up which we sold at $\$ 4.00$ per bushel, f. o. b. Forest City, Arkansas." "This year's crop convinces me that the Rio-Oso-Gem, U. S. Plant 'Patent No. 84, i sthe very finest Peach and has certainly proven such with me. It has very fine qualities as a canner and people go wild about Mr. Charles Heilig. Sewell, New Jersey Gloucester County, said that the most handsome and the which trees, three years old, from which he picked during eerly s Which he sold at an average price of $\$ 5.00$ per bushel at his farm, grossing him more than AMERICA'S MOST FAMOUS PEACH

Mr. E R Connor fruit (1) years old, he picked a 300 -bushel crop for the Peaches in smaller quantities at high prices to his customers throughout the Shenandoah Valley of Virginia and nearby cities. He planted 100 more trees two years ago which had a few Peaches on Patent No. 84, planted in his Orchard instead of 500 .

\section{RIO-OSO-GEM IS A "MUST" FOR EVERY GROWER} near future you will see where the Rio-Oso-Gem, U. S. Plant Patent No 84, will be getting more prominence each year. It is predicted that within a decade or so, it will be the mast extensively planted commercial Peach in Americo.

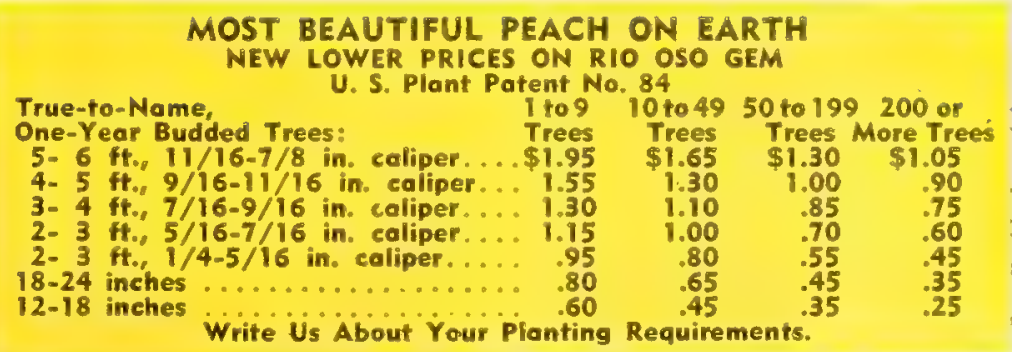

RIO-OSO-GEM PEACHES BRING DOUBLE PRICES COMPARED TO MOST VARIETIES Every year the Rio-O so-Gem brings highest prices of any variety on the American markets. 

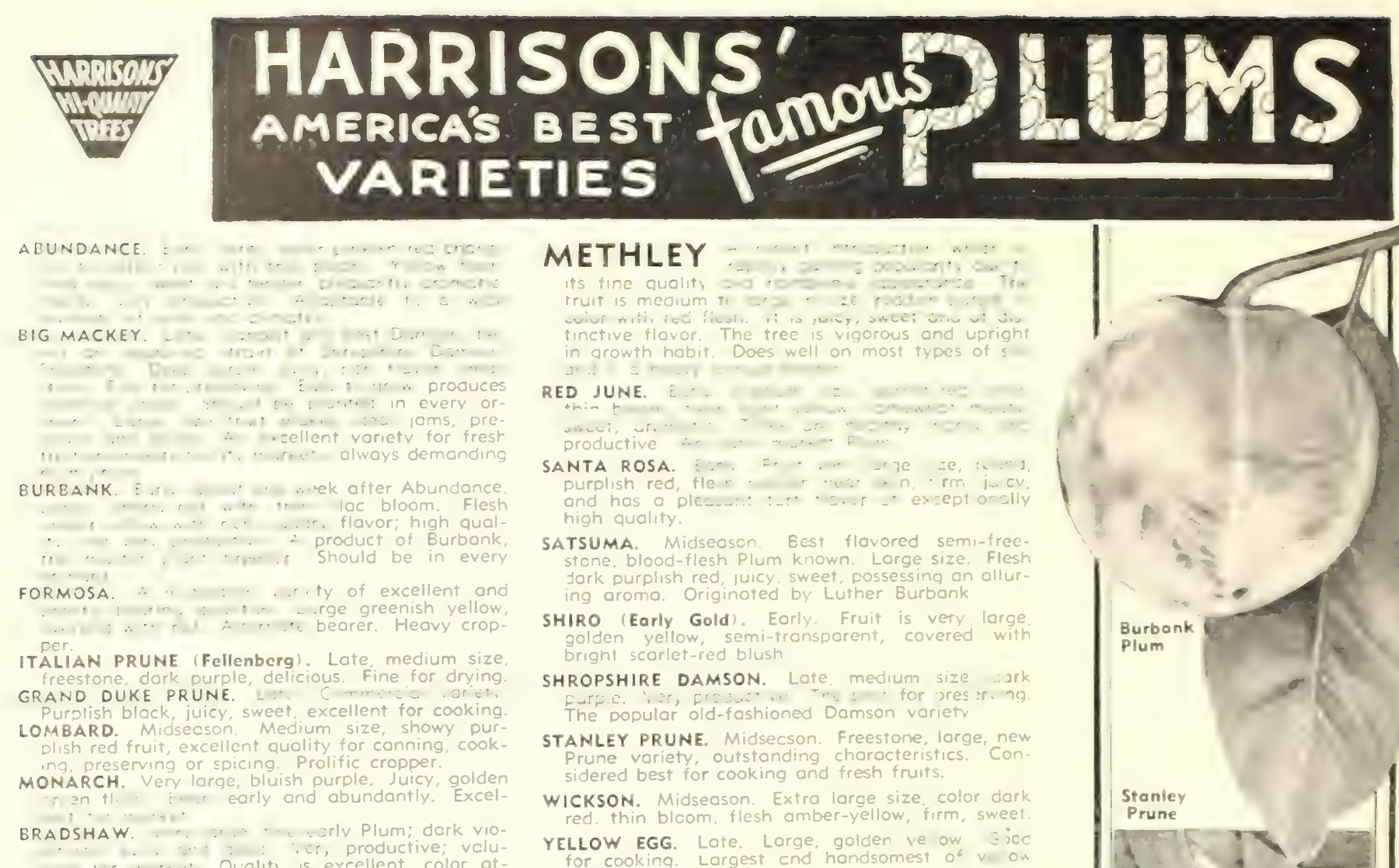

\section{METHLEY}

, $+\cdots+\cdots+\cdots+\cdots, \cdots$

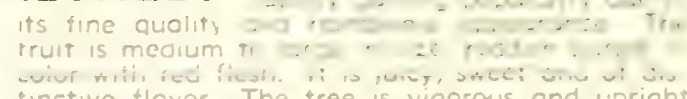

RED JUNE. E.

ANTA ROSA.

SATSUMA

SHIRO (Early Gold).

SHROPSHIRE DAMSON.

STANLEY PRUNE.

WICKSON.

YELLOW EGG.

HARRISON-GROWN PLUM TREE PRICES

Propogated Direct from "Verified" Varieties of Super-Sel
Certified $100 \%$ Healthy

BUDDED TREES:

5 to 6 feet

4 to 5 feet

3 to 4 feet

Moy be Assorted Varieties of Plum Trees. For Jumbo Size Plum Trees, See Page 17

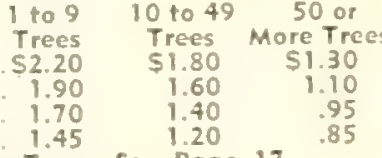

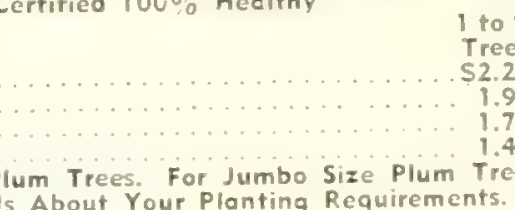

Extra Gaad Fruits for The Hame Garden APRICOTS

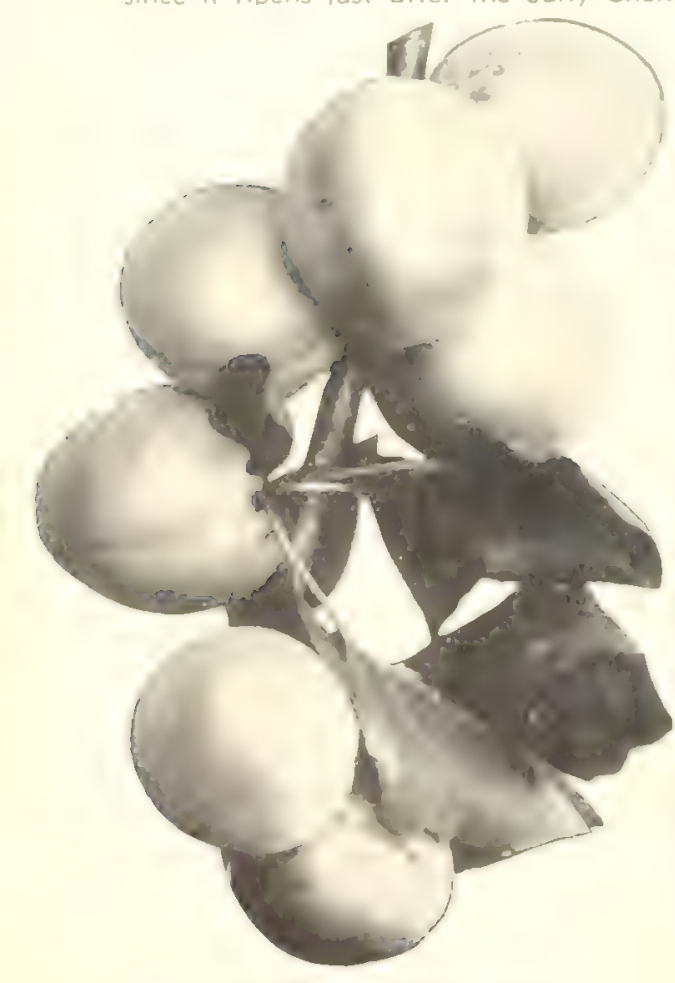

APRICOTS-A Real Trea

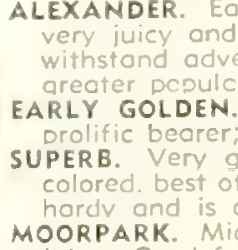

APRICOTS CAN BE GROWN ANYWHERE PEACHES SUCCEED

\section{NECTARINES}

Delicious for Eating

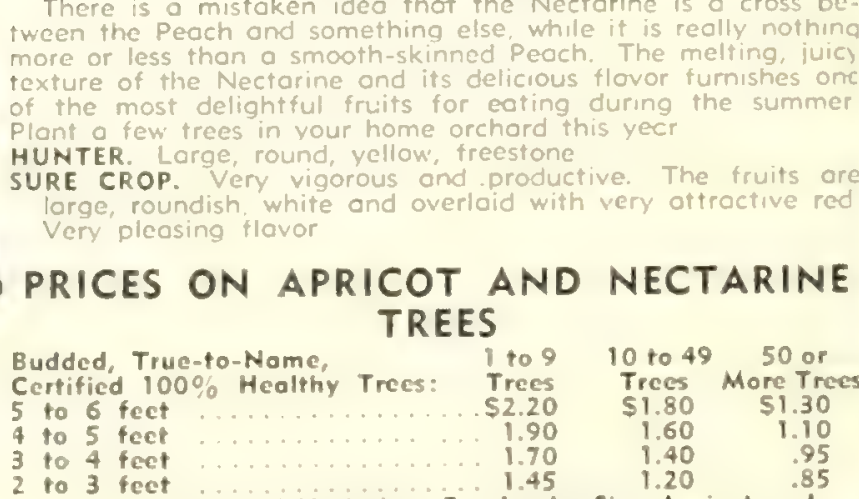

to 3 feet May be Assorted Varieties. For Jumbo Size
Nectorine Trees, See Poge 17.
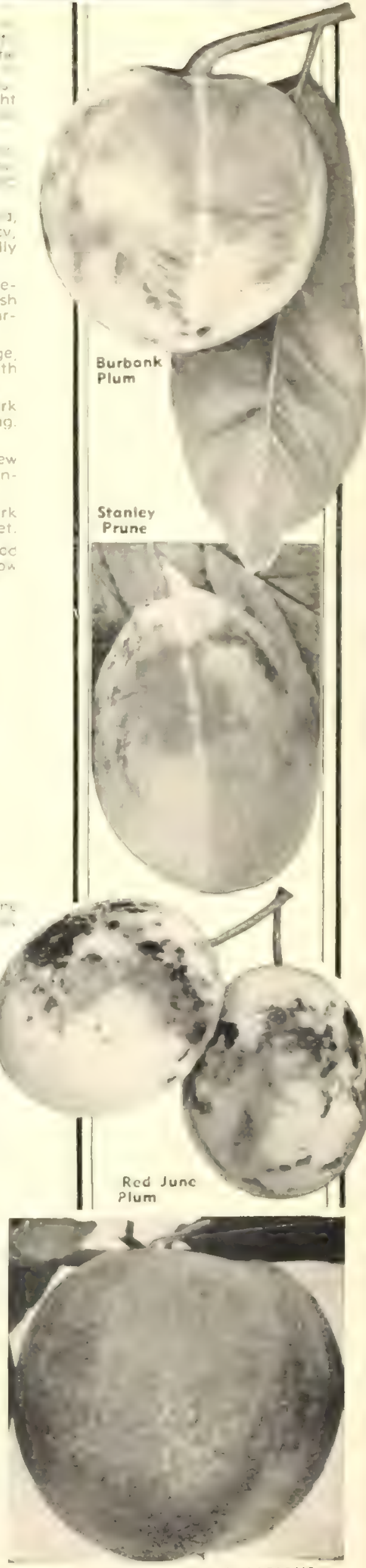

NECTARINES ARE DELICIOUS 


\section{Harrisons' Jumbo Size Fruit Trees are Definitely Superior}

\section{SAVE TWO TO}

THREE YEARS BY PLANTING SUPER-

SIZE FRUIT TREES

HAVING JUMBO

GROWTH

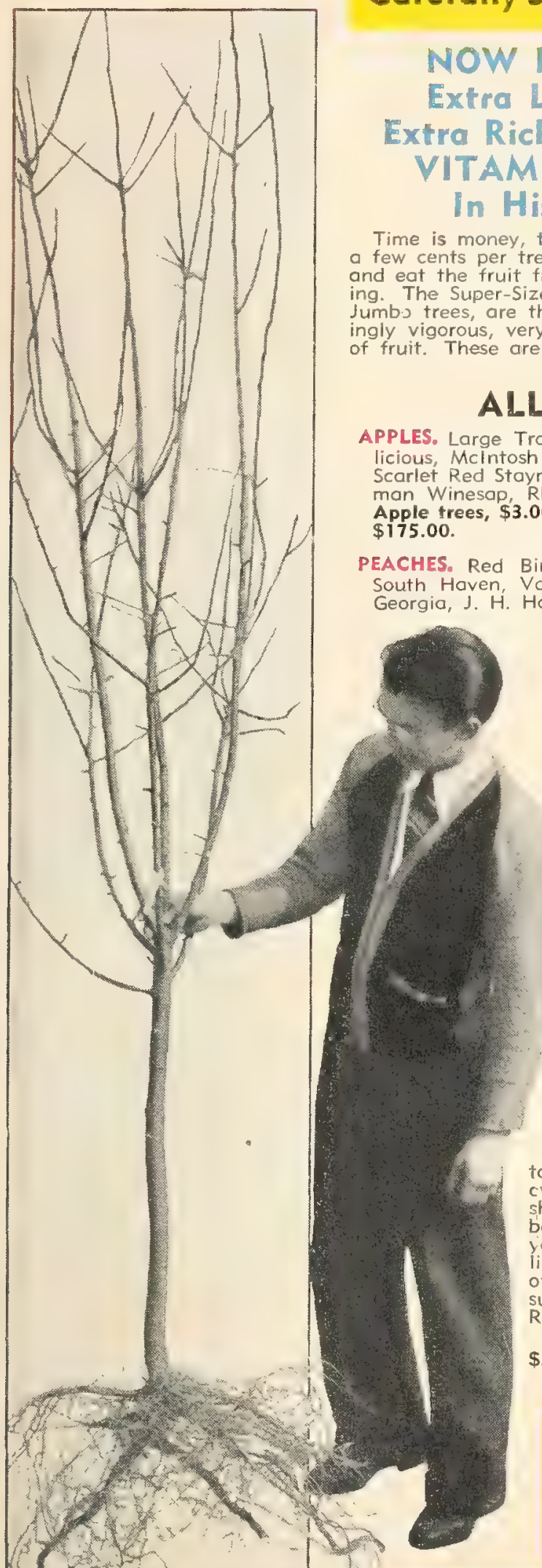

GUARANTEE ON JUMBO TREES

You take no chances when you buy Jumbo trees from

If they are not satisfactory your money will be cheerfully refunded in full, providing they are properly packed and returned within 24 hours after receipt.

\section{Best Trees OBTAINABLE-} Carefully Selected Specimen Trees

\section{Everyone Can Grow \\ Large Rich-Colored,}

Rich-Flavored, Healthful,

AMIN-PACKED FRUIT

His Own Back Yard

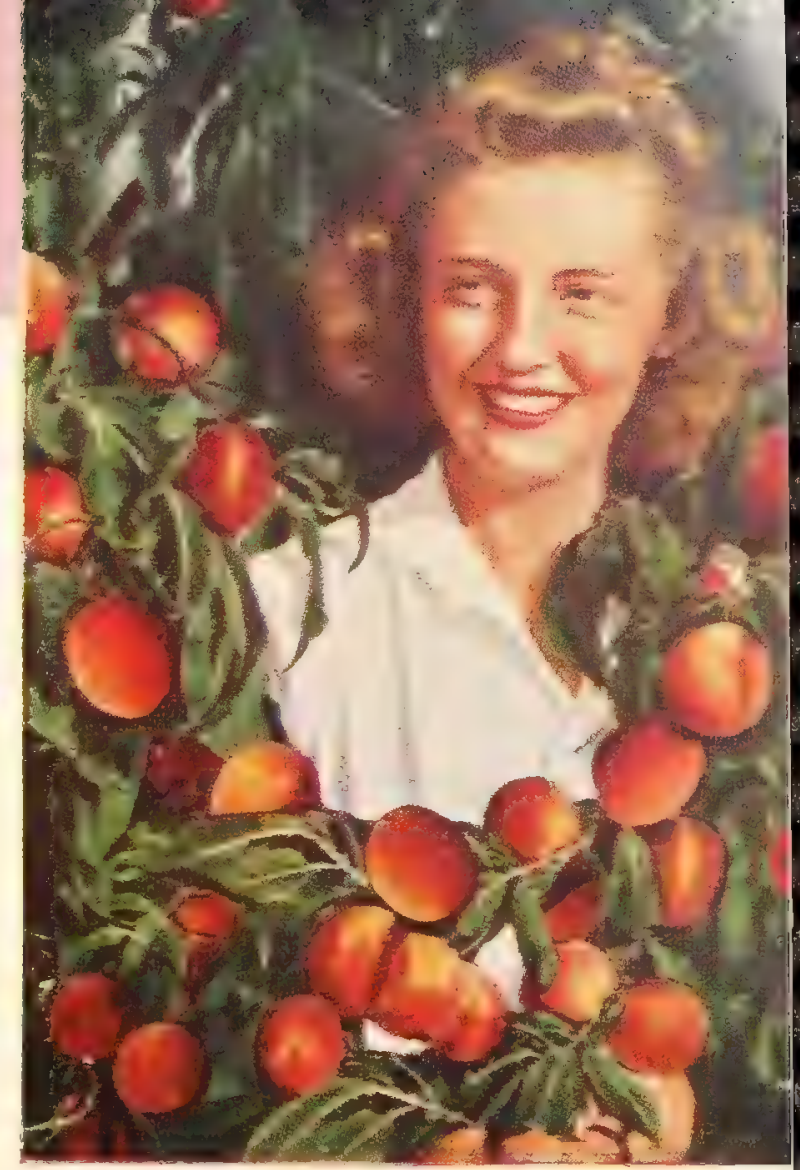

\section{ALL VARIETIES LISTED IN ORDER OF RIPENING}

(Lodi) Williams Early Red, Summer Rambo Super Red Mclintosh Triple Red De-

, Red Yorking, Red Spy, Solid Red Winesap, Double Red Baldwin, Red Rome Beauty, Stay

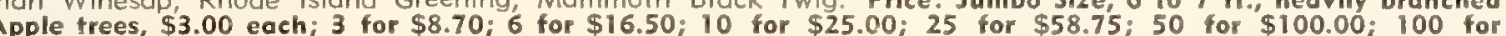

Hale-Haven, Golden East Hiley, SuHtivan Eg Elbertapers Late Red, Bracket, Rio-Pso-Gem Peach trees, $\$ 3.00$ each; 3 for $\$ 8.70 ; 6$ for $\$ 16.50$; 10 for $\$ 25.00 ; 25$ for $\$ 58.75$; 50 for $\$ 100.00 ; 100$ for $\$ 175.00$.

PEARS. Koonce, Clapp's Favorite, Douglas, Bartlett, Kieffer, Buerre d'Anjou. Pricess: Jumbo Size, 6 to $7 \mathrm{ft}$, heavily branched Pear trees, $\$ 3.75$ each; 3 , for $\$ 10.95 ; 6$ fo $\$ 21.00 ; 10$ for $\$ 32.50$.

PlUMS. Red June, Abundance, Burbank, Santa Rosa, Methley, Satsuma, Wickson Stanley Prune, Big Mackey Damson, Grand Duke Prune, Shropshire Damson, Italian $\$ 3.75$ each; 3 for $\$ 10.95$; 6 for $\$ 21.00$; 10 for $\$ 32.50$.

CHERRIES. Black Tartarian, Napoleon, Montmorency (Sour), Schmidt, Windsor. Prices: Jumbo Size, 5 to $7 \mathrm{ft}$., branched Cherry trees, $\$ 3.75$ each; 3 for $\$ 10.95 ; 6$ for $\$ 21.00$; 10 for $\$ 32.50$.

APRICOTS. Alexander, Early Golden, Superb. Prices: Jumbo Size, 6 to 7 ft., heavily branched Apricot trees, $\$ 3.75$ each; 3 for $\$ 10.95 ; 6$ for $\$ 21.00 ; 10$ for $\$ 32.50$.

NECTARINES. Hunter, Sure Crop. Prices: Jumbo Size, 6 to $7 \mathrm{ft}$, heavily branched Nectarine trees, $\$ 3.75$ each; 3 for $\$ 10.95 ; 6$ for $\$ 21.00 ; 10$ for $\$ 32.50$.

\section{SPECIAL JUMBO SIZE}

\section{BLUEBERRY PLANTS}

Have already fruited in the nursery. Ready cwn grounds and of luscious berries on your shrub or Rose bush. You can pick delicious berries the first season planted, and each little attention. We only have a few hundred of these jumbo sized plants to offer. Can supply in the following varieties only: Cabot, Prices: Jumbo size, 4-year-old, 2 to $3 \mathrm{ft}$. $\$ 3.75$ each; 3 for $\$ 10.50$; 10 for $\$ 32.50$.

Harrisons' Maryland Grown Jumbo Fruit Trees are the Finest Quality in the World
For a New Orchard or for Replanting Bearing Orchards Use Jumbo Bearing Size Fruit Trees for the Quickest and Best Fruiting Results Why Waste Space with Missing Trees? Superior Strains Eorliest to Beor True to Name

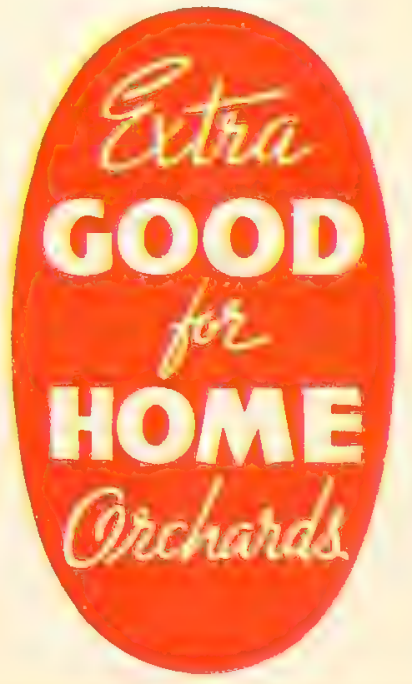

A Jumbo Size Apple Tree Will Aurnish You Fruit and Shade, Too
Harrisans' The Nation'1 Truit Tree Nurseries 


\section{HARRISONS \\ BEAR BETTER CROPS \\ OF BETTER FRUIT.

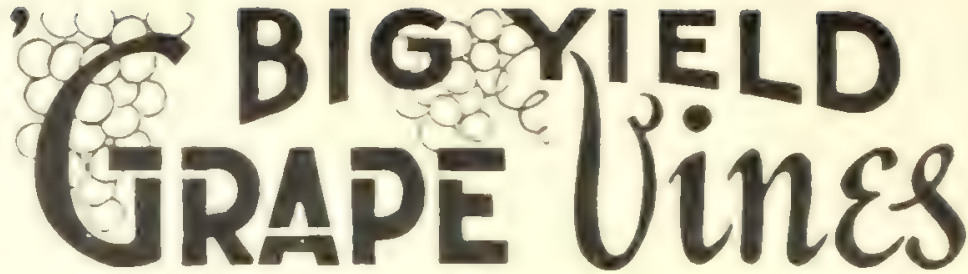

Harrison Brothers Selected Varieties Grapes AGAWAM

CACO

CATAWBA.

DELAWARE.

FREDONIA.

NIAGARA.

WORDEN.

ut better in quolity. It is sweeter lorger in bunch ond

berry. Several days earlier. Valuable for garden and vineyard.

PRICES-HARRISONS' BIG YIELD GRAPE VINES

Dependable, True-to-Name-Plant During 1949

All Varieties

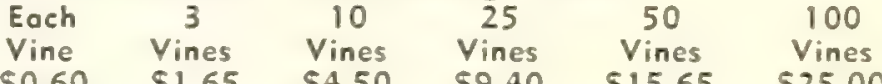

RED-WHITE-BLUE

Victory Grape Vineyard

OFFER No. 22

$2 \mathrm{Niaga}$

All for $\$ 2.70$

\section{PLANT THE BEST}

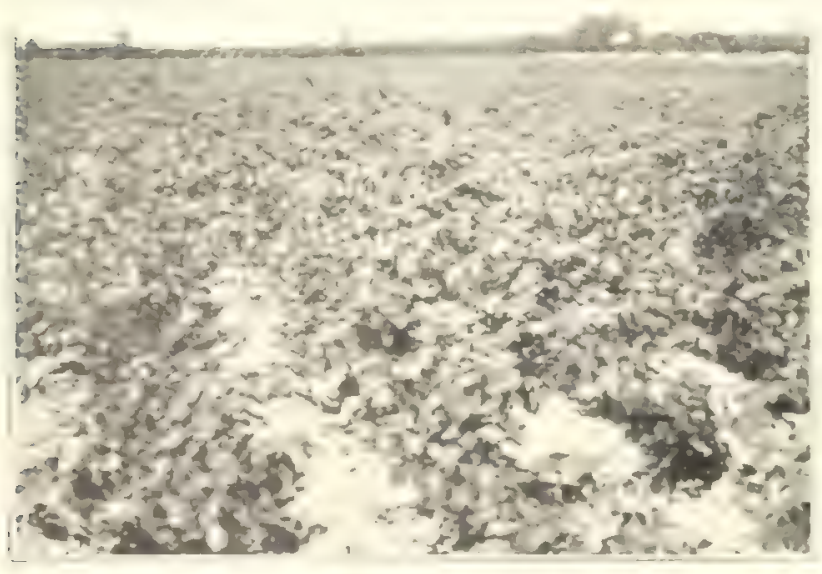

Harrison Brothers Grow of Berlin, Maryland, the Grape Vines We Scil
GRAPES - One of the Easiest Fruits to Grow in the Home Garden

For Bigger and Better Crapi Plant CONCORD Harrisons' Super Strain

Blue midseason. The most popular and extensively planted Grope in It adapts itself to vorying conditions ond is state in the union. Large, compact bunches of dork purplish black colored

Exceptionally Heary Yields

rated as the best money-

Harrison Brothers

Are Large Growers of Dependable Grape Vines for Planters

Everywhere

Get Your Grape Arbor or Vineyard Started This Year

\section{For Quick Crops Plant JUMBO GRAPE VINES}

\section{Big crops of luscious Gropes, some the} first seoson plonted. No other fruit bears Jumbo Grope Vines have olreody fruited only in Jumbo size; listed in their order of ripening: Fredonia, Worden, Concord, Agowom, Niogora, Catowbo.

Prices: $90 \mathrm{c}$ each: 3 for $\$ 2.40$; 6 for $\$ 4.20$; 10 for $\$ 6.50 ; 25$ for $\$ 13.75$; 50 for $\$ 25.00$ We con fumish the following varieties 


\title{
Plant Nut Trees
}

\section{For Edible Foods and Landscaping \\ d

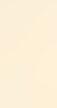

\section{CHINESE CHESTNUTS}

Now You Can Grow Chestnuts!

Blight-Resistant Chestnut Trees

Only two years from this fall, right in your own grounds, you can pick big, fat, tasty Chestnuts from the trees you plant this year! Remember gathering Chestnuts in the good old days - hoven't you felt sorry for your children because they couldn't? The devastating blight that stripped our forests of the native Chestnut was an American tragedy! Now these hardy, blight-resistant Chestnut trees will bring them back. More than that, you need not wait 15 to 20 years for nuts - they'll bear year ofter year!

Plant in abundance Harrisons' strain of Chinese Chestnut Trees.

PRICES: 2 to $3 \mathrm{ft} ., \$ 3.50$ each

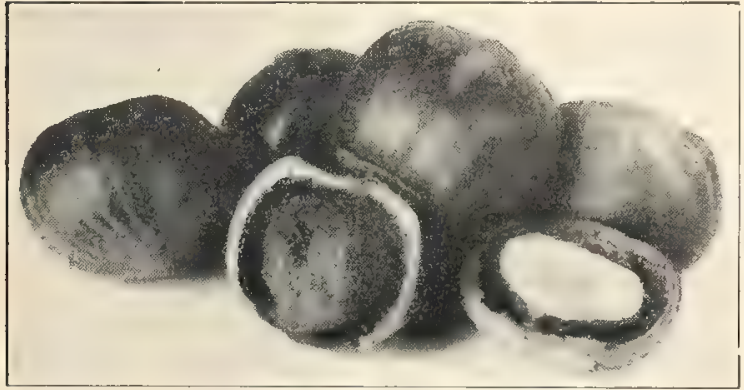

AMERICAN FILBERT (Hazel Nut

NEW LOWER PRICES

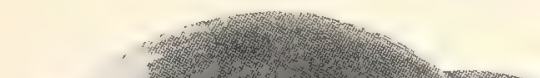

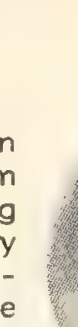

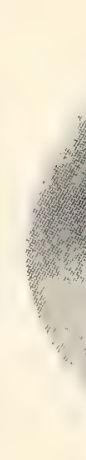

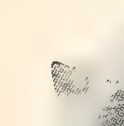




\section{Grow Finer Flavored Berries}

With Marrisons' 'sacritied Raspberry Plants

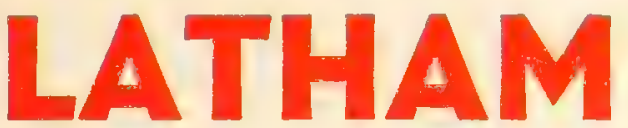

WORLD'S LEADING RASPBERRY

The sensational yields of this variety have at tracted the attention of growers everywhere, and all those who have given it a trial are praising the many unusual features they have found in Latham. After thoroughly testing Latham we find it a remarkable variety in every respect; you will be both delighted and surprised after giving it a trial.

\section{Large Berries-}

\section{Tremendously Productive}

Latham is a tall, vigorous grower, the canes are extra heavy, well able to support the load of fruit. The foliage is healthy, dark green, tough and leathery, highly resistant to insects. Latham ripens with Cuthbert, covers o

longer fruiting season. The berries are beauties and will cause a sensation wherever they are shown. Many are over an inch in diameter and they hold this size to the end of the season. Color dark, rich red.

NEW LOWER PRICES

OF RED RASPBERRIES-ALL VARIETIES Selected Plants, I-Year, No. I Grade

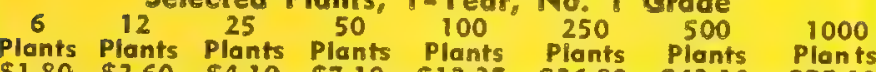

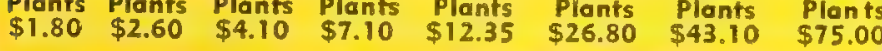
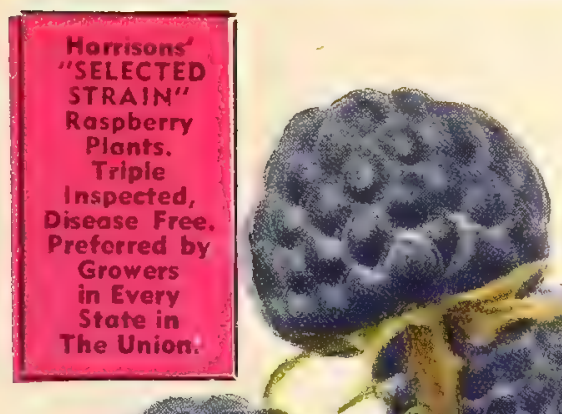

HARRISON BROTHERS NURSERIES BERLIN, MARYLAND

CUMBERLAND
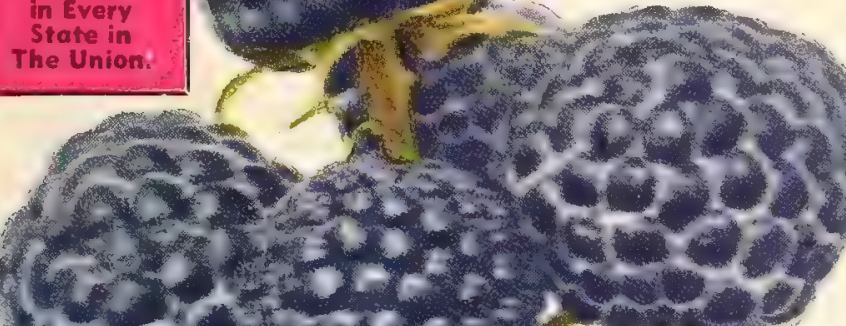

$+9$

Whes (1)
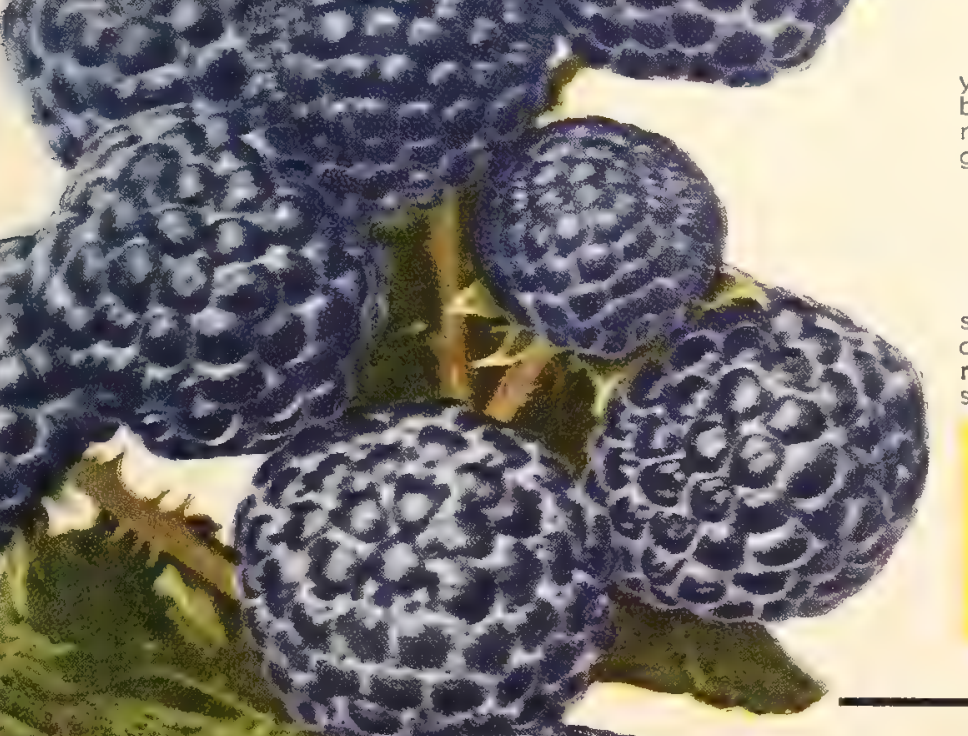

$x^{2}+x^{2}$

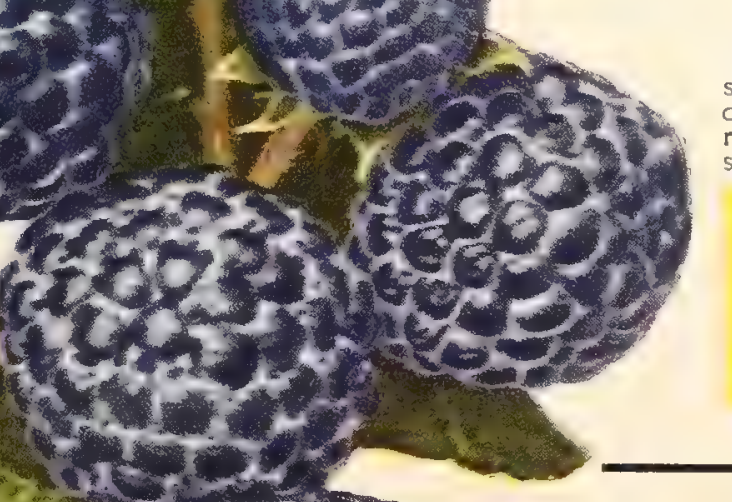

\section{Every Garden Should Have \\ INDIAN SUMMER}

\section{Sensational New Everbearing Raspberry}

A dish of big red juicy Raspberries sprinkled with sugar and swimming in pure cream, it can be yours for every meal from June into July, and again from mid-September until frost, if you will plant Indian Summer. Makes tasty, scarlet-red sauce or pie and flinest jams and preserves you ever tasted. Frozen Indian the year 'round.

Indian Summer Raspberries are no experiment; they have fruited successfully for thousands of gardeners in nearly every section of the country. This is truly a champion for your garden. Order early.

\section{The Mast Papular Black Rasplerry}

handsome appearance that it is sure to bring the top prices on the market.

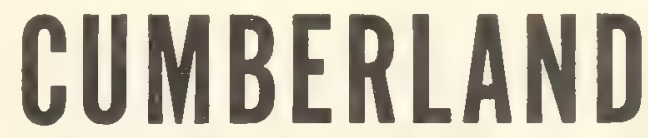

Midseason to late. This is the most popular Blackcap of the present time, because of its great

\section{A BIG CROP EVERY YEAR}

Cumberland has never been known to fail to produce a big crop every year. This variety is perfectly hardy and tremendously productive, the not equalled by any other variety in quality, flavor and appearance. It's good to eat and good to sell.

\section{Here's Another Extra Good Blackcap}

The Mammoth New MORRISON sized berries, glistening jet-black color, rich flavor, fewer seeds, heavy pro-
ducer. The thrifty. strong, hardy plants are heavily rooted and disease resistant. Easy to grow, excellent for canning, eating fresh, freezing. Ripens ightly later than Cumberland.

\section{NEW LOWER PRICES}

OF BLACK RASPBERRIES SELECTED PLANTS All Varieties, 1-Year, No. I Tips $\begin{array}{cccccccc}6 & 12 & 25 & 50 & 100 & 250 & 500 & 1000 \\ \text { Plants } & \text { Plants } & \text { Plants } & \text { Plants } & \text { Plants } & \text { Plants } & \text { Plants } & \text { Plants } \\ \$ 1.45 & \$ 2.10 & \$ 3.30 & \$ 5.70 & \$ 9.90 & \$ 21.40 & \$ 34.50 & \$ 60.00\end{array}$

INCREASE YOUR PROEITS WITH 


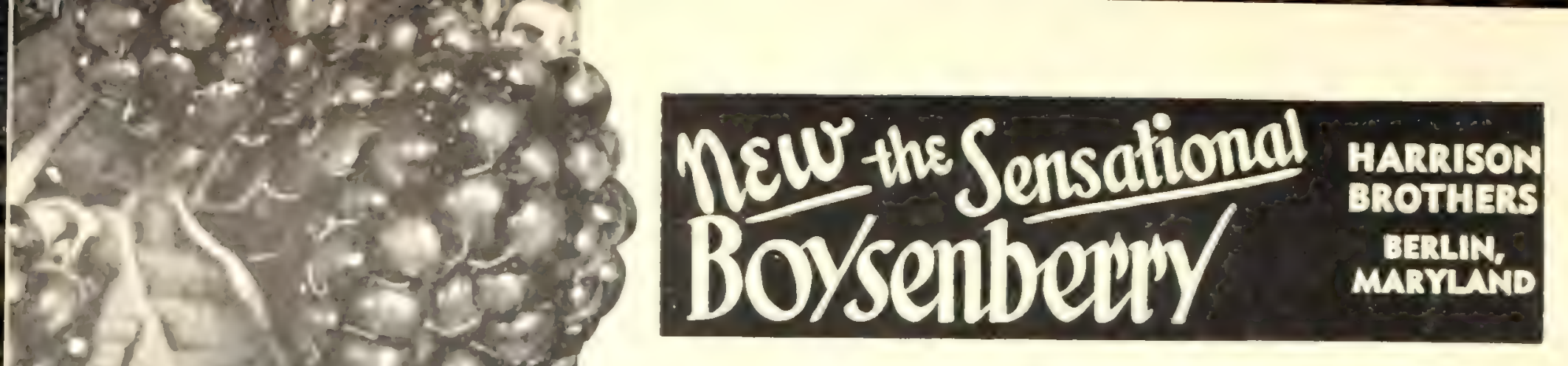

The New Mammoth Berry That Will Revolutionize the Berry-Growing Industry

Two Inches in Length

Lucretia Dewberry

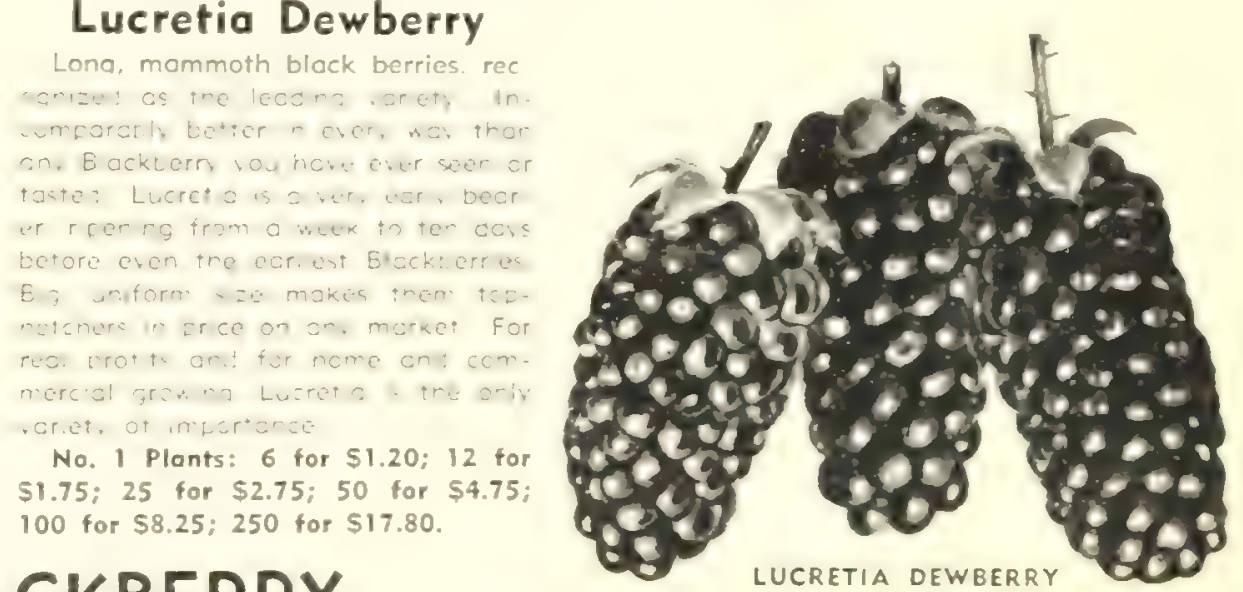

\section{ELDORADO BLACKBERRY}

A Heamy Yielding Blachberry

that Spells Succes1 Eueryuhere

\section{CURRANTS}

Lorge, 1-yr. bunches, $\$ 1.00$ each; 3 for $\$ 2.85$ :

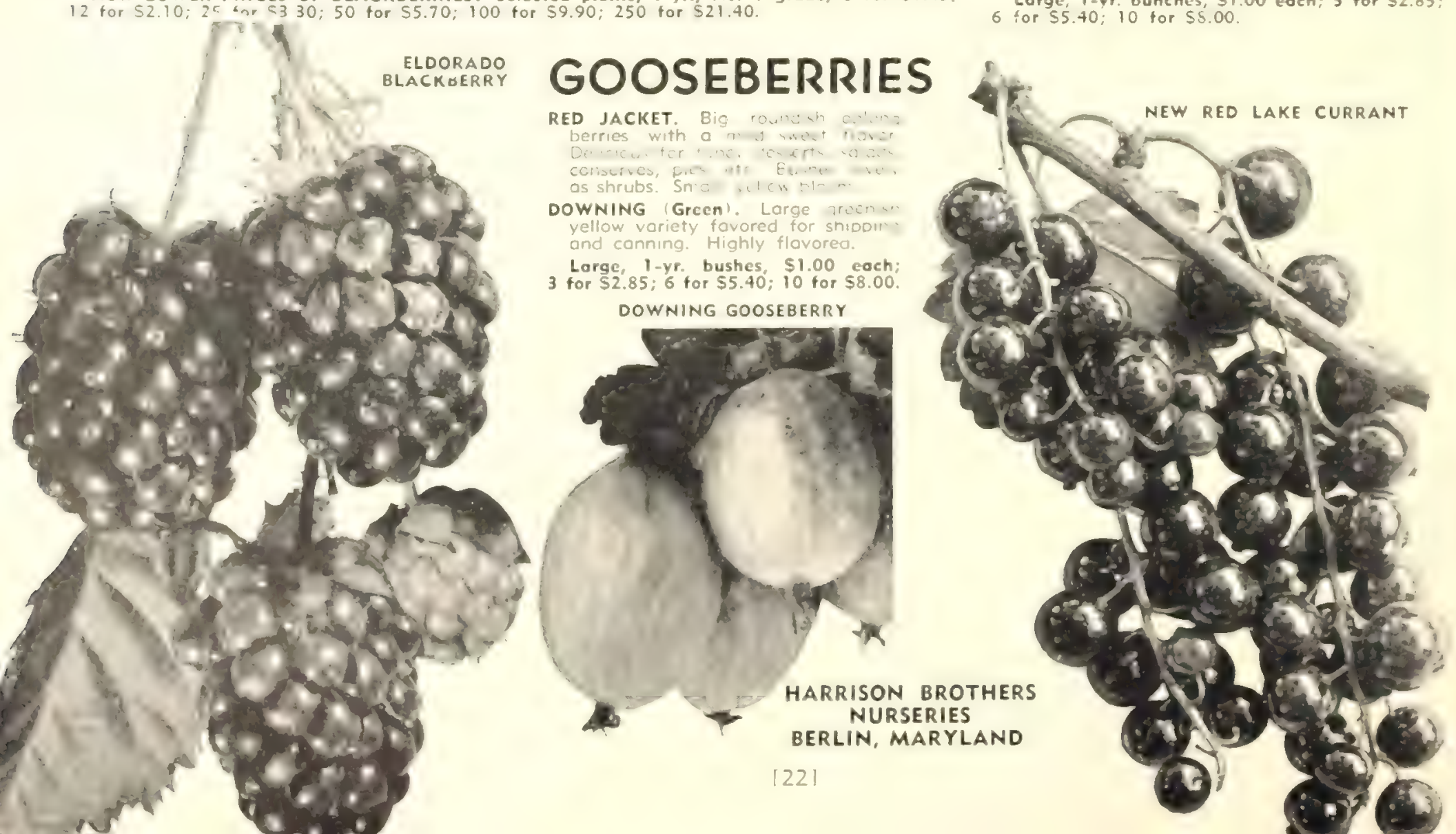




\section{Grom Yaur Own DELICIOUS! NUTRITIOUS}

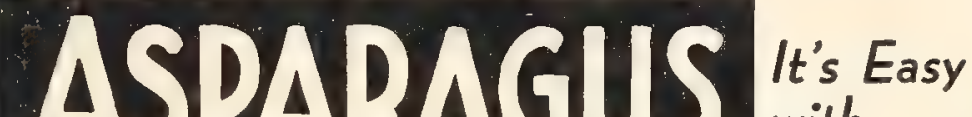 with}

\section{Harrisons' "Big Yield Strain" MARY WASHINGTON}

\section{Highly Profitable and Easily Grown}

Being the first vegetable to come in the spring it alwoys brings a high price on the markets. Stalks being delicious and very healthful, every garden should have a generous supply and when properly set and cared for will last a lifetime.

\section{The Famous True-to-Name Mary Washington}

Plant This Pedigreed Strain

There is no variety of Asparagus as good as Mary Washington and whether you are growing for home use only or for market you cannot afford to grow any other. This wonderful new Asparagus was developed and introduced by the U.S. Department of Agriculture and although it is just a recent introduction it has become famous the country over.

\section{Rust-Resistant-Profitable}

Growers everywhere are discarding all other varieties in favor of the famous Mary Washington, because it is earlier, the stalks are larger, more tender and more productive than any other variety and more highly immune to rust, which means that one planting will produce profitable crops for many years.

\section{Large-Early-Tender-Juicy}

Asparagus buyers now demand Mary Washington and are willing to pay fancy prices to get it. The demand for Mary Washington is tremendous because when it is once eaten, no other variety will give satisfaction. The stalks are purplish green color, large, tender and juicy. A very rapid grower, which means many cuttings.

Prices of Genuine Pedigreed Mary Washington Asparagus Roots

$\begin{array}{ccccccc}25 & 50 & 100 & 250 & 500 & 750 & 1000 \\ \text { Roots } & \text { Roots } & \text { Roots } & \text { Roots } & \text { Roots } & \text { Roots } & \text { Roots }\end{array}$
$2-Y$ r. No. $1 \$ 2.35 \$ 3.75 \$ 6.00 \$ 12.00 \$ 18.75 \$ 24.75 \$ 30.00$ $\begin{array}{llllllll}1-Y \text { r. No. } 1 & 1.50 & 2.50 & 4.00 & 8.00 & 12.50 & 16.50 & 20.00\end{array}$

\section{New Gigantic Red MacDonald Rhubarb}

If you want something different, something delicious in garden fruits, then plant some of this grand new MacDonald Rhubarb.

Stalks are of giant size on mature plants, and a rich rosy red in color. This beautiful color carries through the stalk. Sauce made from it has the red color of a dish of Strawberries. Flavor is mild and pleasing. This new Rhubarb does not send up seed stalks and never becomes tough or stringy. Just cut in small chunks and cook. Do not remove the tender skin; it cooks right up with the stalk.

Heavy plants: $\$ 1.00$ each; 6 for $\$ 5.40$.

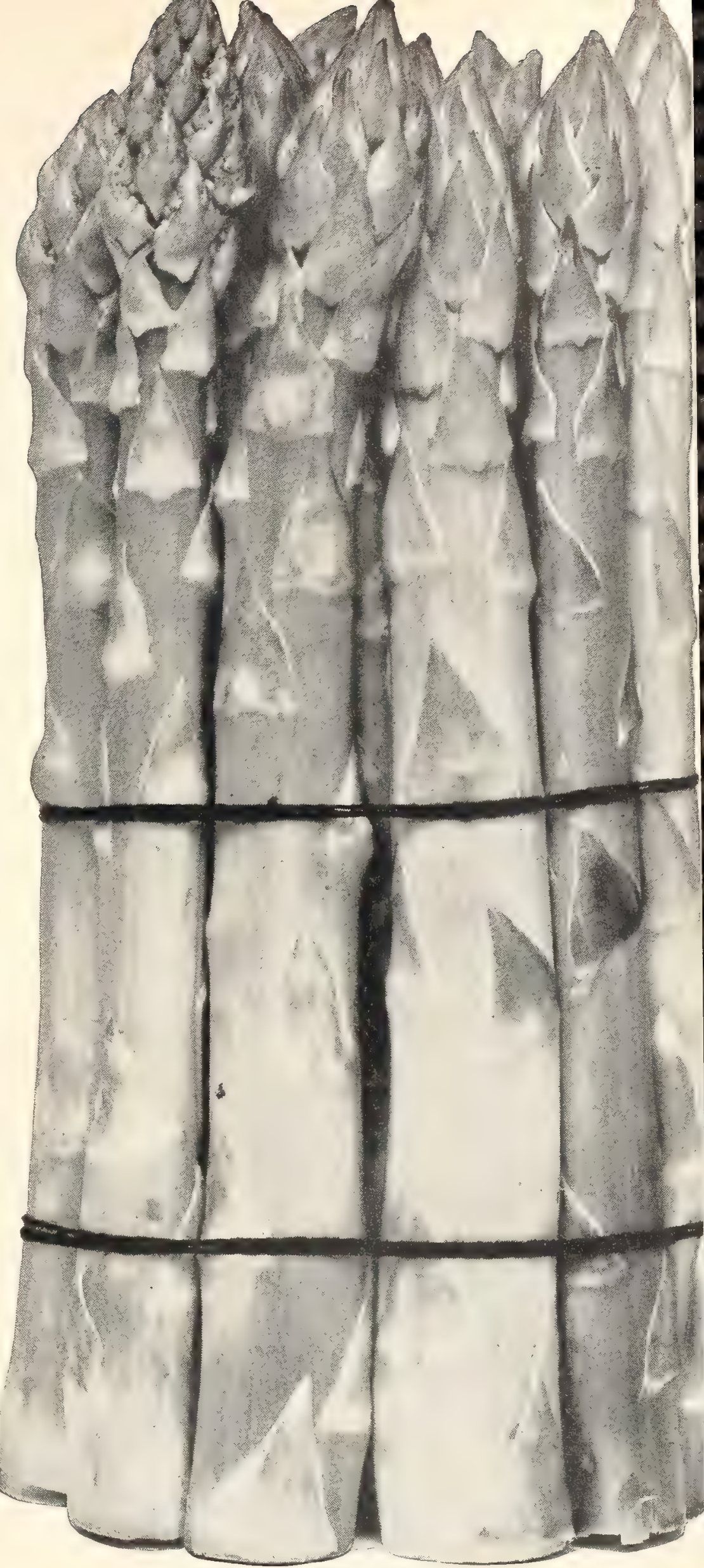

SAVE A YEAR!

PLANT JUMBO THREE-YEAR Mary Washington Asparagus Roots

Yes, you can grow your own delicious tender Asparagus quick by planting our jumbo size roots. These roots are the cream of our three-year-old crop and have already borne large, early, tender, juicy Asparagus in the nursery. to other kinds.

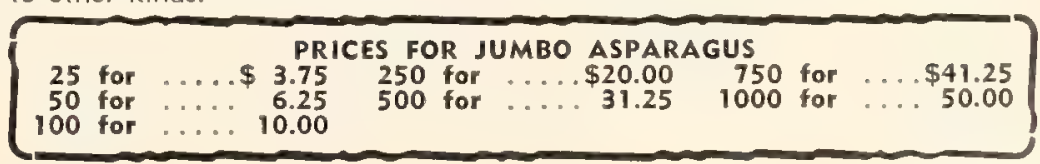




\section{Pick World's Finest Strawberries From}

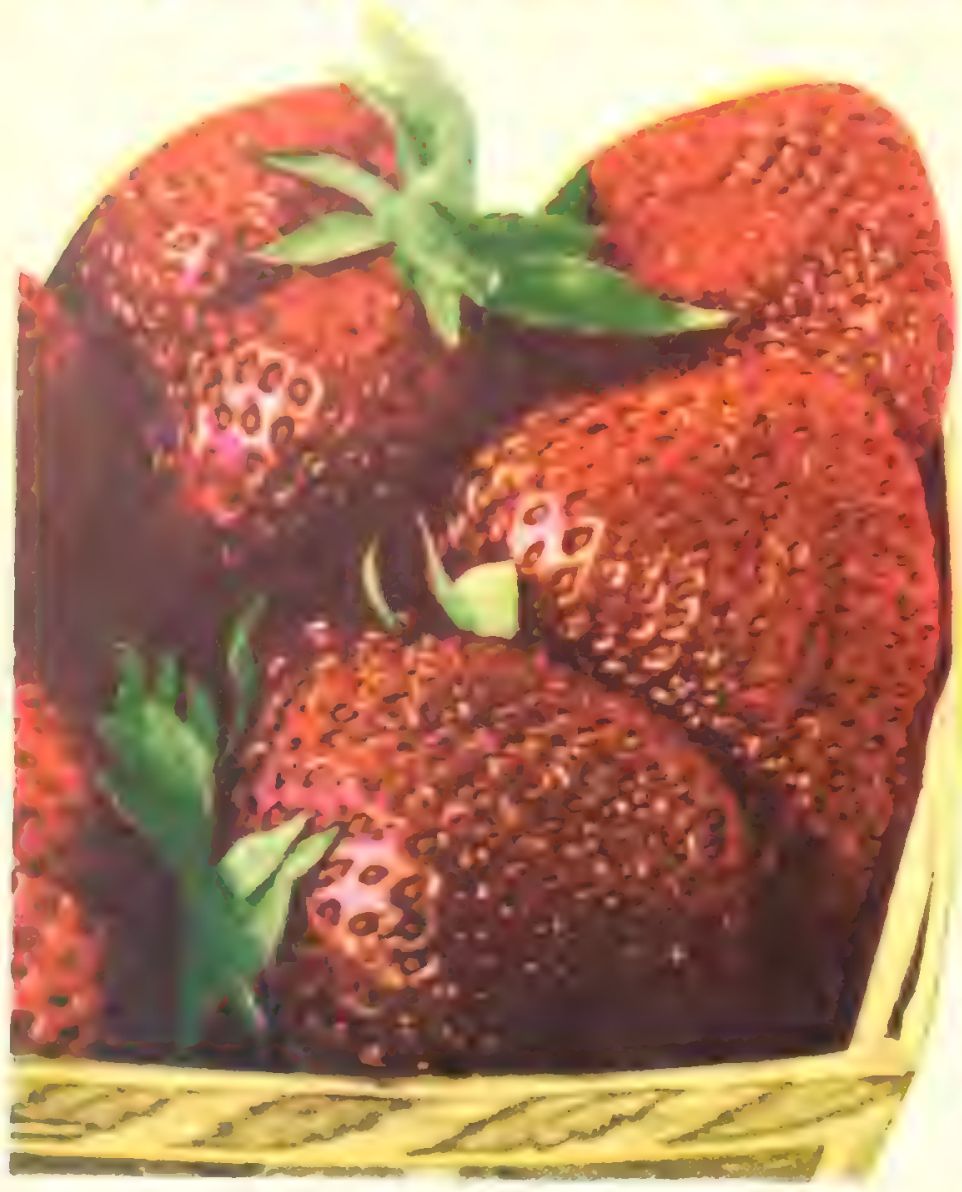

\section{Your Own Plants}

A Big Profit From Your Own Bock Yard

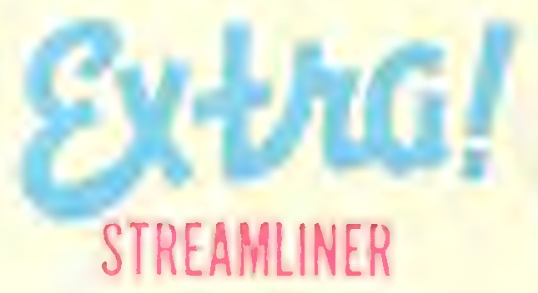

The Greatest Everbearing Strawberry EXCELLENT FOR EATING FRESH OR FREEZING MAKES HEAVY FRUITING BED

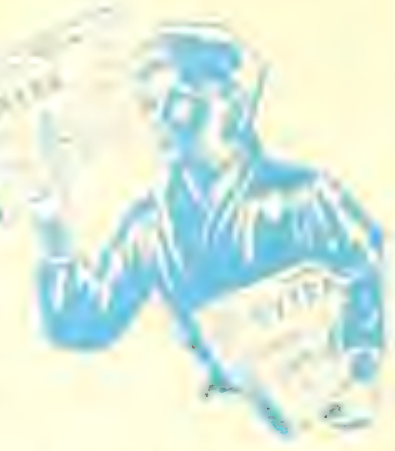

Harrisans' Euerbearing MASTODON A TRIPLE YIELD

1 -Plant this spring

2-Pick first crop, July to frost

3 -Pick second crop, June next yeor. 3 REAL CROPS - 3 BIG PROFITS

Bears in 90 Days, and, too, It's the Best Fomily Garden trowberry-Loads of Big Berries in 90 Doys

WHY WAIT A WHOLE YEAR?

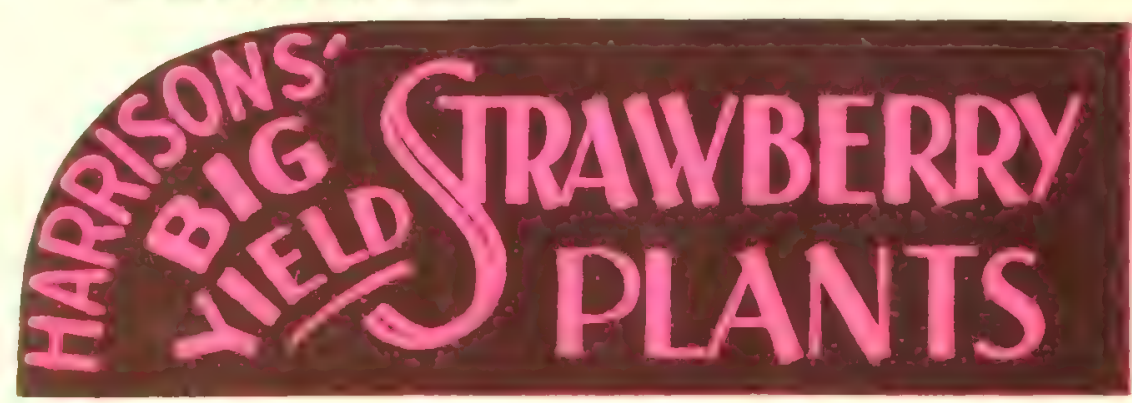

Dependalle - Hardy - True - ta - Name Harrisons' Selected Strain "Big Yield" Strawberry Plants Are Better

HARRISONS' BIG YIELD STRAWBERRY PLANTS

EARLY: $25 \quad 50 \quad 100 \quad 250 \quad 500750 \quad 1000$

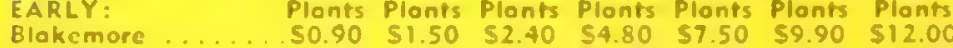

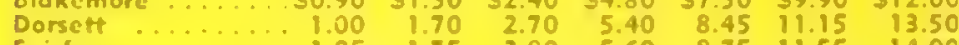
Foirfax

Premier

MIOSEASON

Big Joe

Cotskill

Temple

Chesapeake

Red Stor

EVERBEARING $\begin{array}{lllllll}1.05 & 1.75 & 2.80 & 5.60 & 8.75 & 11.55 & 14.00\end{array}$

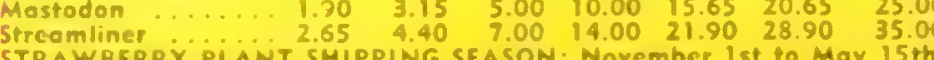
$\begin{array}{lllllll}1.05 & 1.75 & 2.80 & 5.60 & 8.75 & 11.55 & 14.00\end{array}$ STRAWBERRY PLANT SHIPPING SEASON: November Ist to MaY 15 th 


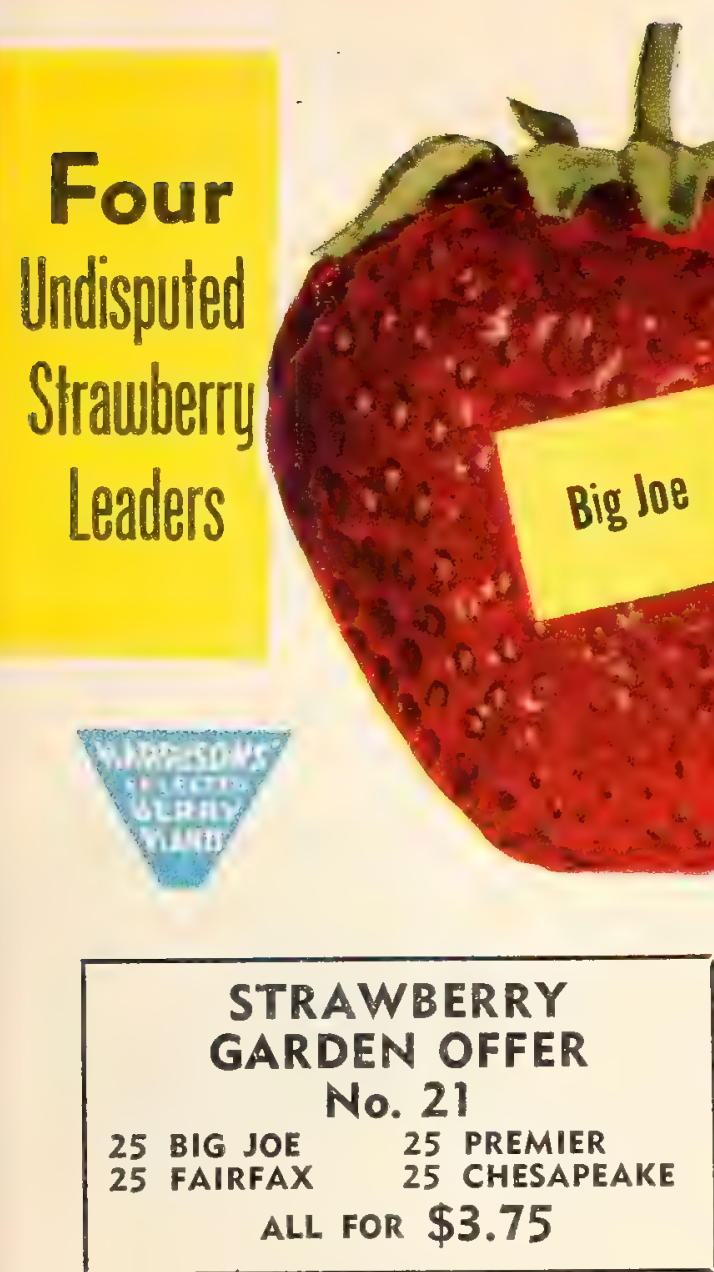

\section{BLAKEMORE}

No Strawberry has become so popular so quickly as Blakemore. It is the most popular fore Premier and is equally dependable, producing big crops every year. The plant is healthy and stands up well during drought. The berries ore large, firm, an attractive red and good quality. Fine for canning and preserving because it holds its color and shape so well.

\section{DORSETT; Early}

Large Fruit-Vigorous Grower-Heary Crops

Dorsett berries average large size, consider ably larger than the Premier; in fact, their size is comparative with Chesaperake, which is the outstanding late berry. Plant growth is exceedingly vigorous, being far more vigorous than of fancy, light red berries.

\section{FAIRFAX, Early}

The Sugar-Saving Berry

Color is a deep, full red; its rich, sweet flavor brings buyers back for more. Fairfax berries are exceptionally firm, making it an ideal shipper. Superior to all for home use, equal to any for commercial planting.

\section{PREMIER Early Berries}

Too well known to need much description. The standard early berry by which all other va rieties are judged. Holds all records for big crops and big profits. Premier has filled more crates, made more dollars, and brought joy ever grown.

Adapted to All Soils-Heavy Yielder. I thrives on most any type of soil and is a ram pant plant maker. Premier fruits extra early when berries are selling at a high price. It is a big yielder of big, bright red berries of fine flavor. For home gardens, local markets, or classed all the other varieties.

Harrison Strawbery Plants Are Bred Up for Bigger Yields and Tell the Stony of Harvest Time.
BIG JOE The Old Reliable LARGE YIELD FANCY FRUIT FINE FLAVOR Big Joe is a heavy producer of large, brilliant red berries of extra fine flavor and is firm enough to withstand long shipments. The plants are good growers and heavy yielders. This voriety succe'eds on all types of soil but does extra well with good care and fertility. Be spring. Our big yield strain insures big crops.

\section{CATSKILL Midseason}

A midseason berry that will produce the largest crops of bigger berries of any midseason variety. Catskill is entirely satisfactory as to firmness, quality, color and attractiveness, season of ripening and climatic adaptation. The highest record of marketable berries was made with this variety. In shipping respects it ranks with Chesapeake and Lupton. It is rated equally as attractive as Fairfax or Dorsett. The berries makes it easier to get at in picking.

\section{Here is the Easiest Fo The Successful New Berry to Grow

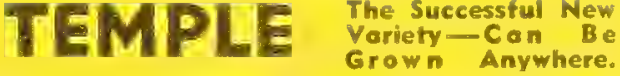

If you have ever tried raising Strawberries and failed, here is the berry for you to try. It will grow on light, sandy soil as well as heavy, water-soaked kinds. The quality of this berry is excellent and its plant growing

characteristics are supreme. Berries are extra large, firm,

beautiful in appearance, fine texture and flavor. Excellent for freezing, canning, eating fresh, olso local and long distance shipments. This berry is the result of years and years of cross-breeding work and is unquestionably the finest new berry for both commercial and home plantings that

has been introduced in many years.

It has our highest recommendation.

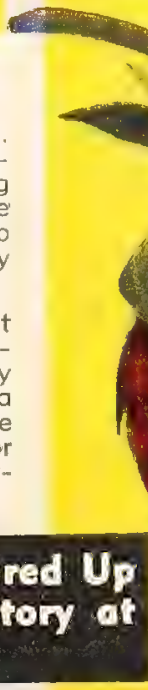

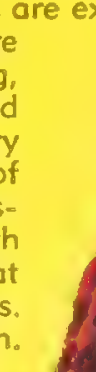

RED STAR HERE'S A NEW ONE This is the other new one by the U.S.D.A. and plenty of money can be made from growing this 


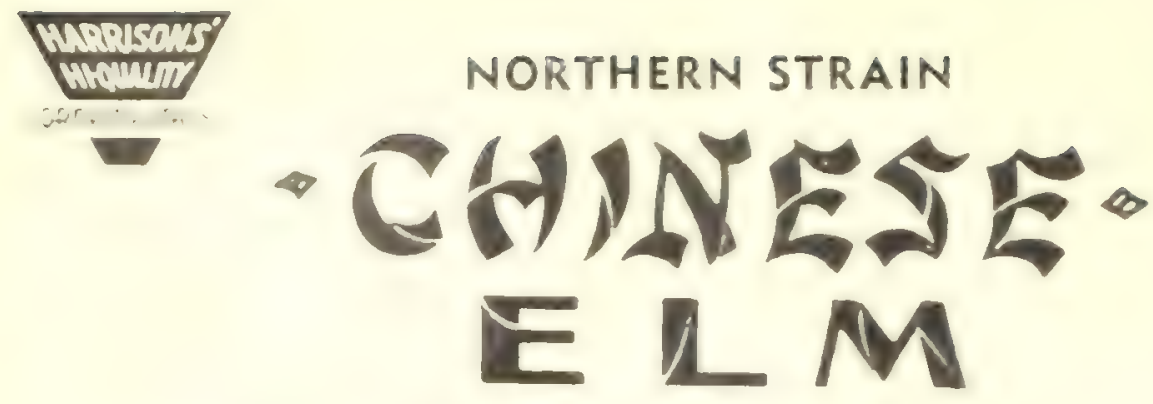

Grows 20 Feet in Four Years
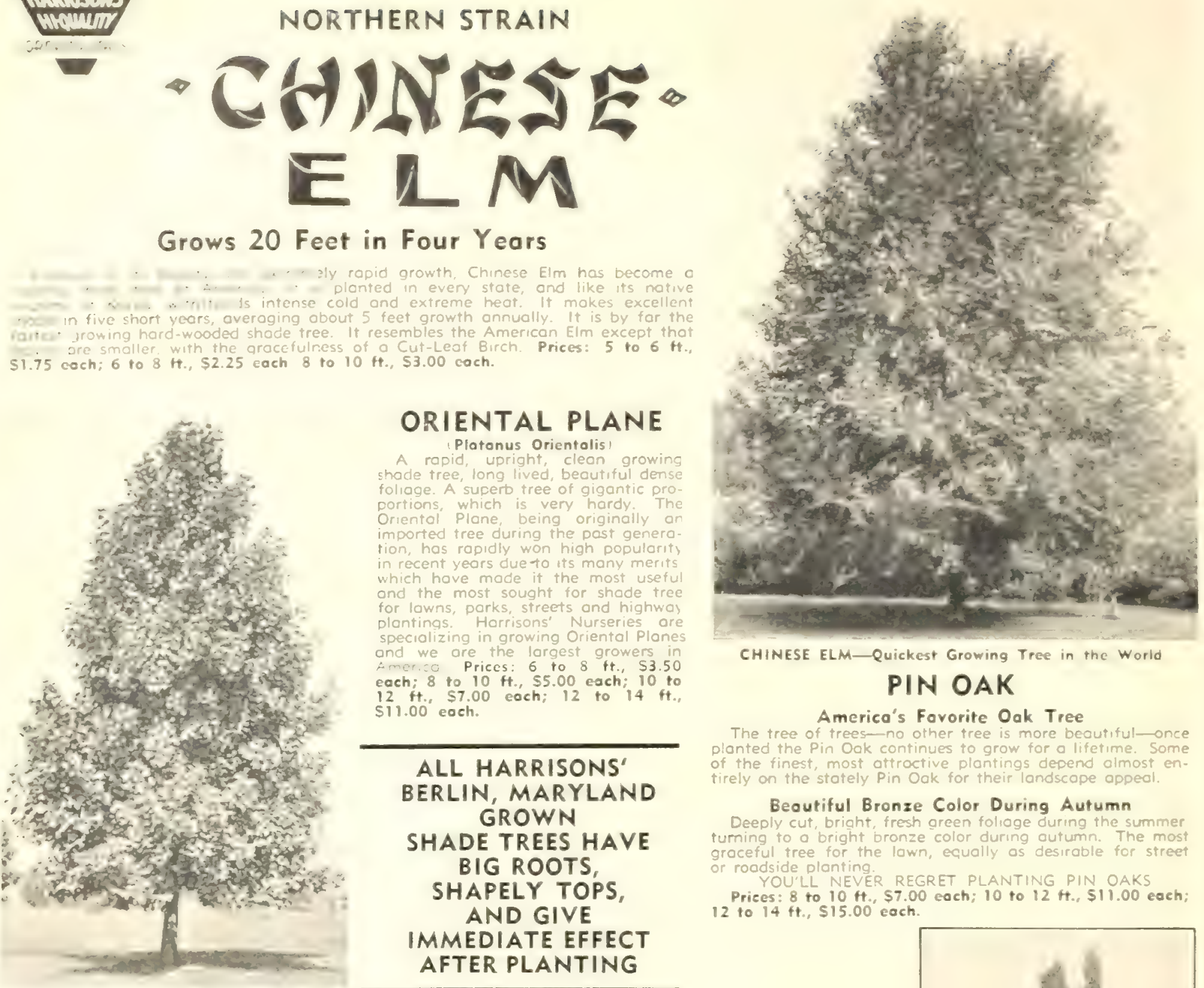

CHINESE ELM-Quickest Growing Tree in the World

\title{
PIN OAK
}

America's Fovorite Oak Tree

\begin{tabular}{c}
\hline ALL HARRISONS' \\
BERLIN, MARYLAND \\
GROWN \\
SHADE TREES HAVE \\
BIG ROOTS, \\
SHAPELY TOPS, \\
AND GIVE \\
IMMEDIATE EFFECT \\
AFTER PLANTING \\
\hline
\end{tabular}

ORIENTAL PLANE

The Famous Light Bark Tree

\section{NORWAY MAPLE}

\author{
(Acer Platanoides
}

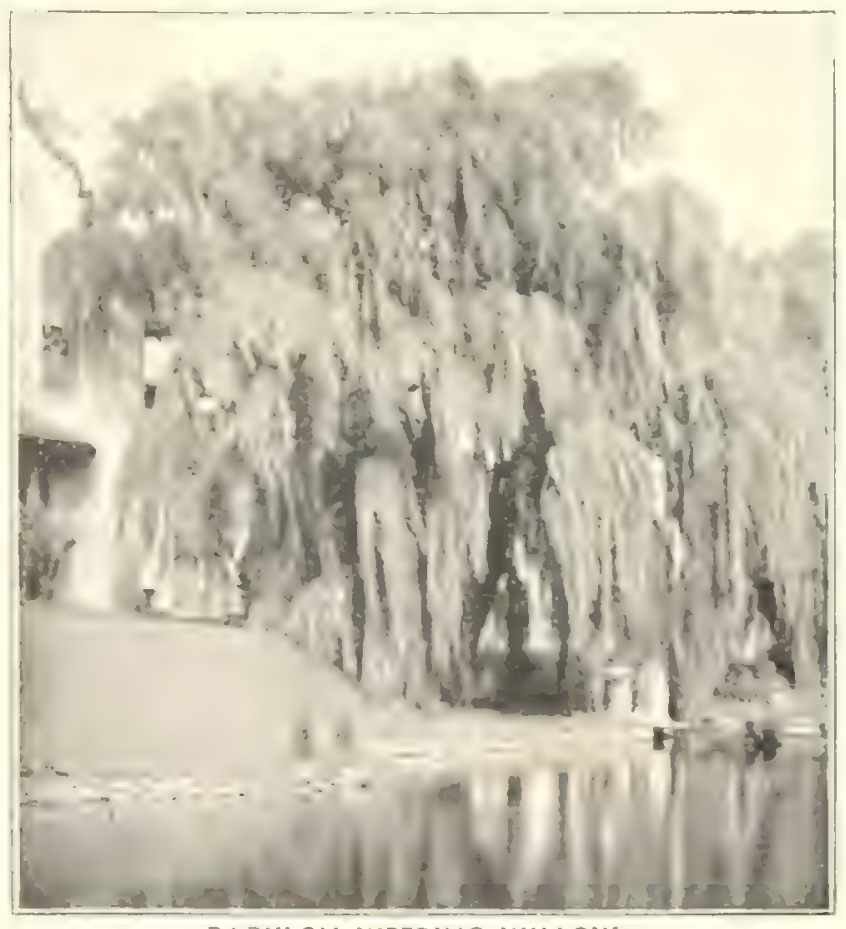

BABYLON WEEPING WILLOW

Typical Mople leoves, large and bright green, fading to gold in the foll. Trunk and branches are sturdy and Prices: 6 to $8 \mathrm{ft}$. $\$ 5.00$ each; 8 to 10 ft., $\$ 7.00$ eoch: 10 to $12 \mathrm{ft}$. $\$ 11.00$ each; 12 to $14 \mathrm{ft}$., $\$ 15.00$ each.

\section{BABYLON WEEPING WILLOW} (Solix Bobylonica)

A rapid growing, hardy tree, thriving in any moist soil. The Willows are valuof their graceful ospect. Prices: 5 to 6 ft., $\$ 1.50$ eoch; 6 to $8 \mathrm{ft}$., $\$ 2.25$ eoch.

\section{LOMBARDY POPLAR \\ (Populus Nigro Itolica)}

A toll, spirelike tree used for sereens and formol plantings. It is fast growing. distinetly omamentol and beoutiful, Prices: 5 to $6 \mathrm{ft}$., $\$ 1.00$ eoch; 6 to 8

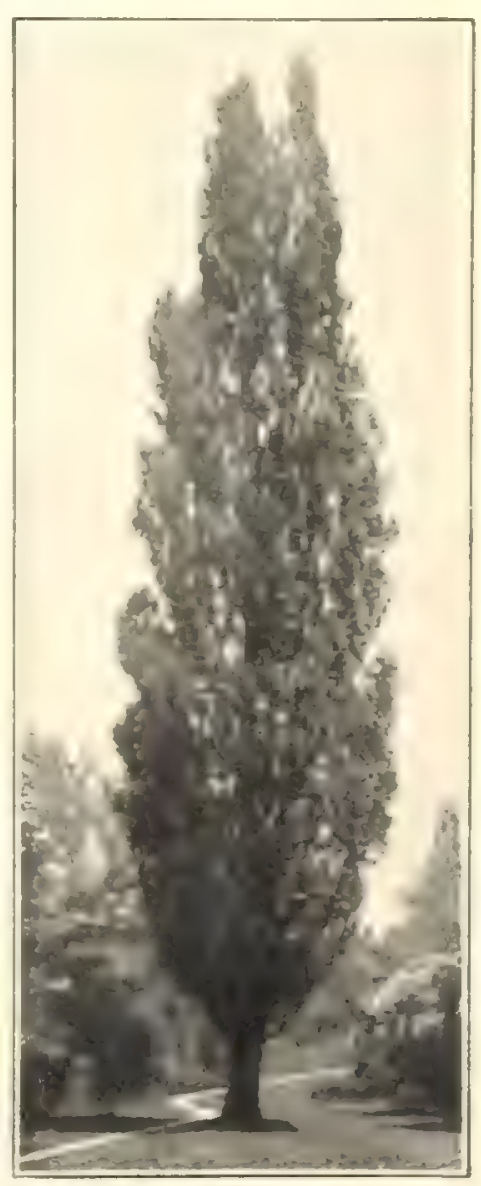

LOMBARDY POPLAR 


\section{HARRISONS' BUD SELECTED

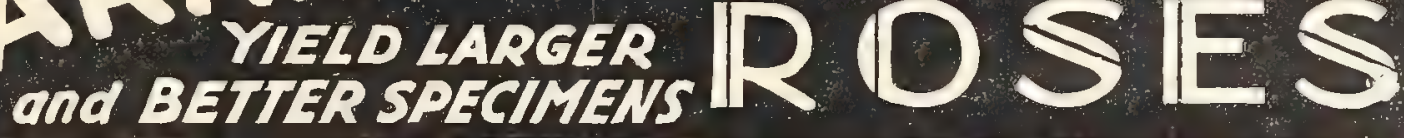

BECAUSE

- Grown under ideal soil and climatic conditions.

- Two-year, field-grown, budded low on de-eyed multiflora Japonica Rose stock.

- Years of experience in growing, packing and handling of Rose bushes.

Scientifically budded from selected mother plants.

- All varieties are fully tested.

( Larger root systems take hold quicker in new locations.

- Packed in moisture retaining material, they arrive in field-fresh condition.

- Graded to higher standards.

a Free from diseases and insects.

HARRISONS' ROSES ARE GROWN BY A SENSATIONAL NEW METHOD

\section{Bud selection method of propago-} tion is a definite improvement in Rose growing. It results in bigger, brighter, better quality blooms in larger quantities with stronger, healthier growing plants. Each and every plant we grow for sale is the offspring of the plant that was especially selected for its free flower ing characteristics, pureness of color and type, vigorous and exceptionalıy free from diseases.

\section{The Calarful PEONIES}

\section{THEY RIVAL THE ROSE}

Once planted they last for years. There should be several planted in every yard. Their flowers during and June furnish an ers for the home. Can supply the following colors: WH ITE, PINK and RED. State col or desire

Prices: 75c each: 3 for $\$ 1.95 ; 10$ for $\$ 5.50$.

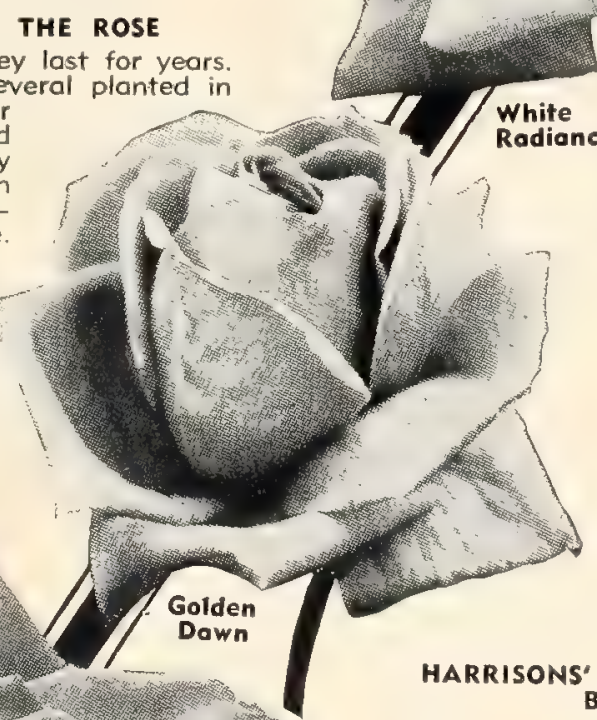

HARRISONS' ROSE YARIETY SELECTION CONTAINS ONLY THE BEST THOROUGHLY TESTED VARIETIES See Page 28 for Other Varieties

\section{HARRISONS" "BUD SELECTED"} EXHIBITION ROSES

EVERBLOOMING HYBRID TEAS

\section{NEW LOWER PRICES}

All Varieties True-to-Name

EYERBLOOMING HYBRID TEAS, NURSERY GROWN BUDDED ON MULTIFLORA JAPONICA UNDERSTOCKS

Super Selected Grade:

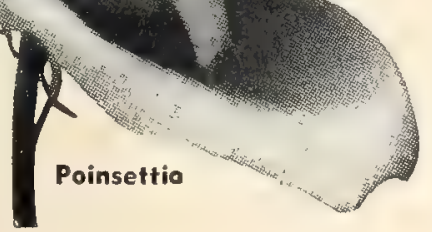

Each 3 for 6 for 10 for

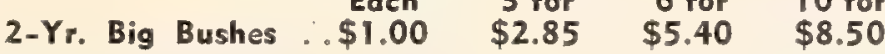

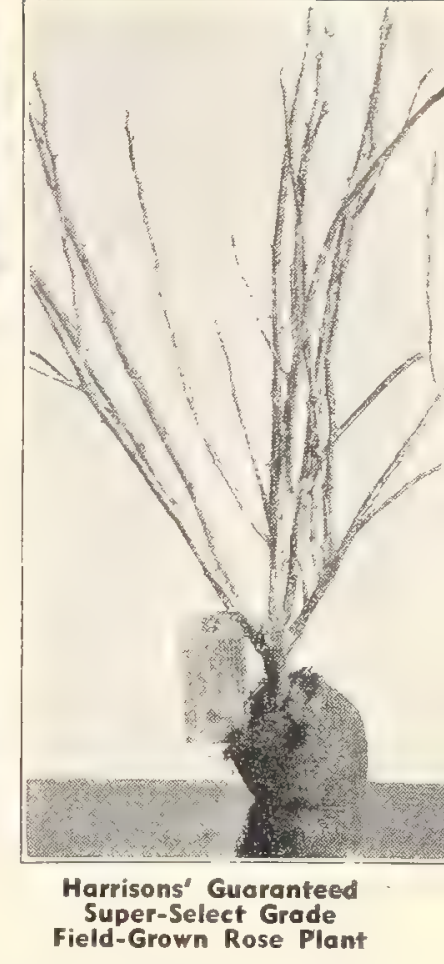

HARDY ROSE PLANTS

We absolutely guarante Harrison Bud-Selected Roses, hordy or hordier the be as harem in any locality noses grown is.

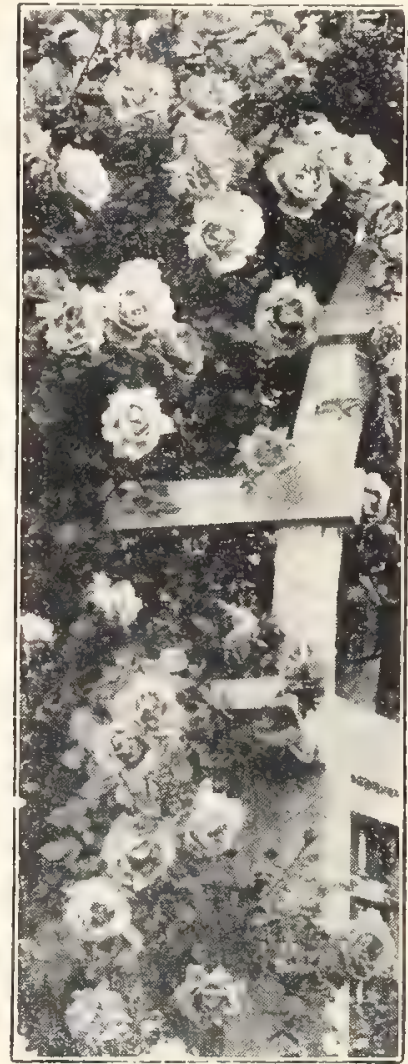

\section{Paul's Scarlet}

\section{Climber}

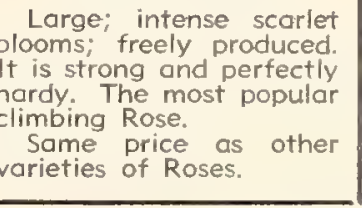

\section{Harrisons' Budded Roses are the Best Why Pay More?}

HAPRISOMS RiVSES 


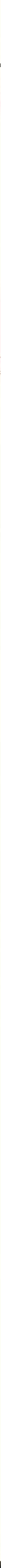




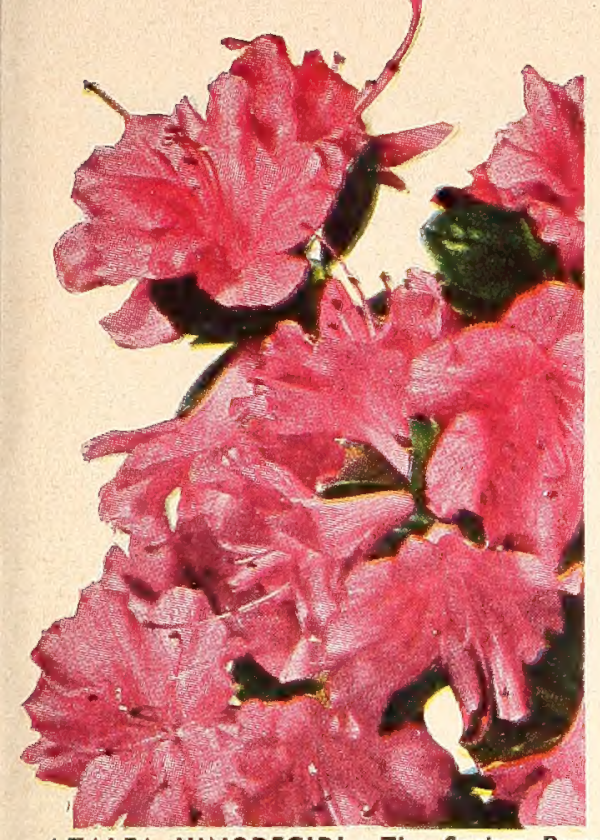

AZALEA HINODEGIRI-The Spring Beauty

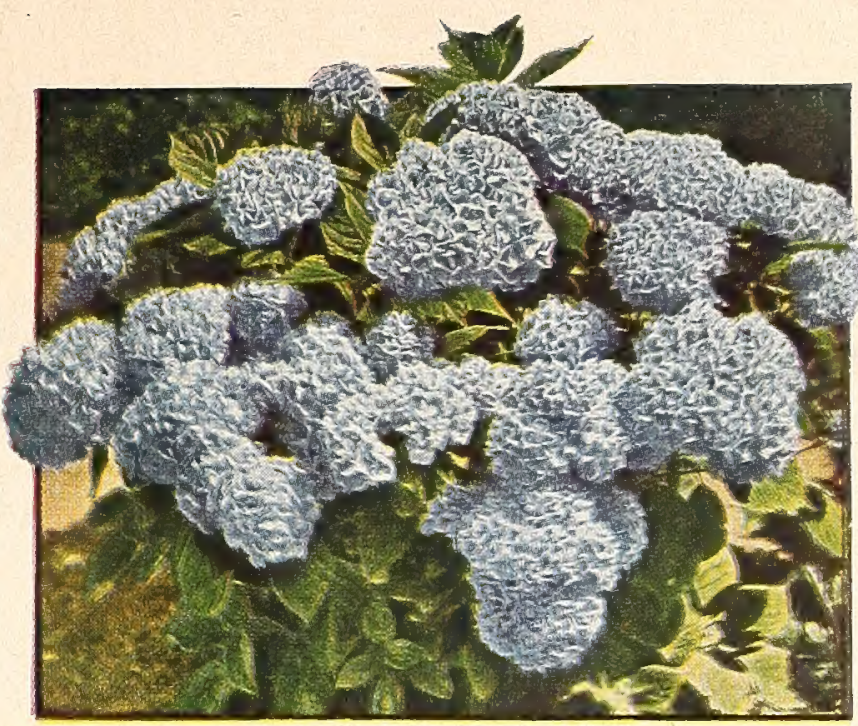

ROYAL BLUE HYDKANGEA

Here's Three Outstanding Shrubs That Belong To Every Home

\section{AZALEA HINODEGIRI Deep Coral-Pink Flowers}

Azalea Hinodegiri is a dwarf grower with evergreen foliage. In the spring it produces profusion of deep coral colored blossoms, complanting around the foundation of homes or planting color in front of evergreens. Grows well in the shade or sunlight.

4 to 6 inches

6 to 8 inches

8 to 10 inches
Each
$\$ 1.00$
1.50
2.00
SPECIAL OFFER No. 29

\section{Azalea hinodegiri. 4}

1 Royal Blue Hydrangea.

Bush Arbutus.

$$
\text { FOR ONLY } \$ 3.75
$$

ROYAL BLUE HYDRANGEA Hydrangea Otaksa Old favorite southern Hydrangea. When win-
ters are severe we suggest heeling in. Large ters are severe we suggest heeling in. Large
balls of blue flowers and attractive large leaves. Color depends on acidity of soil. Field-
grown plants, $\$ 1.50$ each; 2 for $\$ 2.80$.

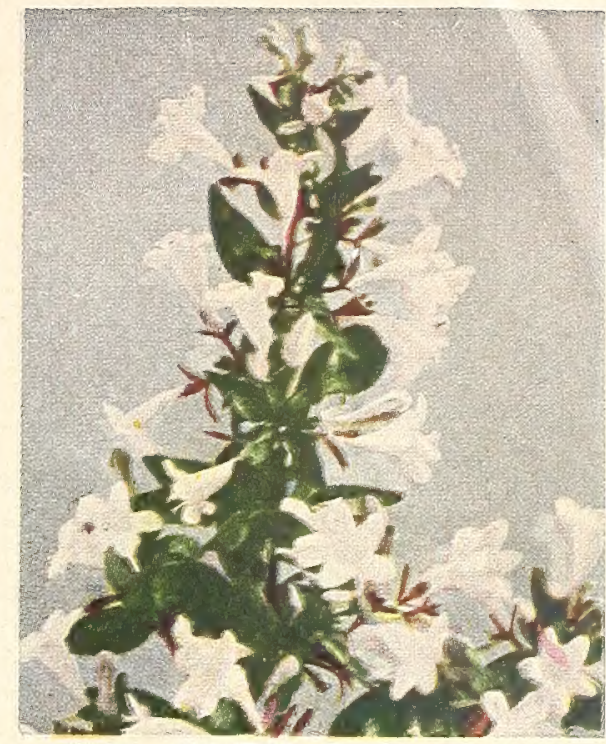

BUSH ARBUTUS-Everblooming

\section{BUSH ARBUTUS (Abelia}

By Far the Best Evergreen Shrub One of our beautiful, popular and sotisfoctory broad-leaved evergreens. The graceful, drooping stems and branches are covered with dark, glossy leaves which in winter assume a metallic sheen. From the middle of June until frost, this plant produces an immense quantity of tubular-shaped white flowers tinged with pink, about on inch long, which are borne in clusters. Good for shady locations.

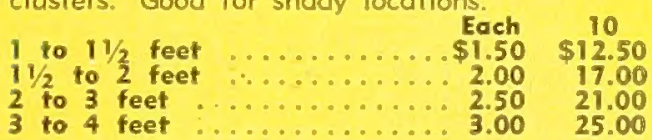

AMERICA'S FINEST FLOWERING
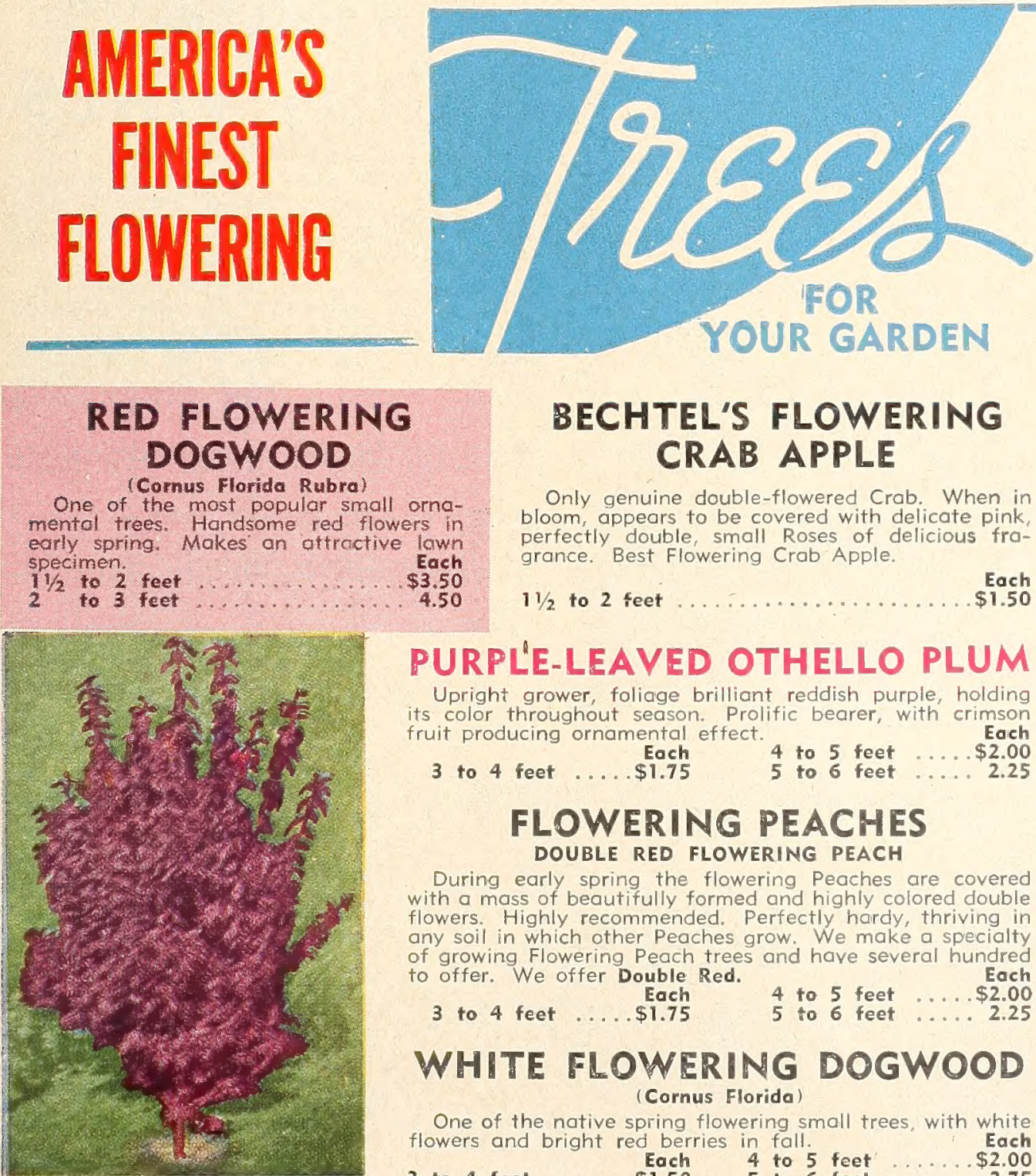

PURPLE-LEAVED OTHELLO PLUM

\section{BECHTEL'S FLOWERING CRAB APPLE}

Only genuine double-flowered Crab When in bloom, appears to be covered with delicate pink, perfectly double, small Roses of

$11 / 2$ to 2 feet

Each
$\$ 1.50$

\section{PURPL'E-LEAVED OTHELLO PLUM}

Upright grower, foliage brilliant reddish purple, holding
color throughout season. Prolific bearer, with crimson $\begin{array}{lll}\text { Each } & 4 \text { to } 5 \text { feet } \ldots \ldots \\ 3 \text { to } 4 \text { feet } \ldots .00 \\ \text { E }\end{array}$

FLOWERING PEACHES DOUBLE RED FLOWERING PEACH

\section{EXTRA!}

NEW WEEPING FLOWERING PEACH

A beautiful red Flowering Peoch that has a decided weeping effect. This Peach has bloom and weeping charac teristics, somewhat similar to Japanese Weeping Cherry. A fine new discovery that is worthy of planting in every lawn or garden. Each

1 to 2 feet

$\$ 1.25$

2 to 3 feet

1.75

3 to 4 feet

2.25

\section{DOUBLE PINK FLOWERING PLUM \\ A vigorous grower, every branch producing double, pink flowers, an 18 to 24 inches

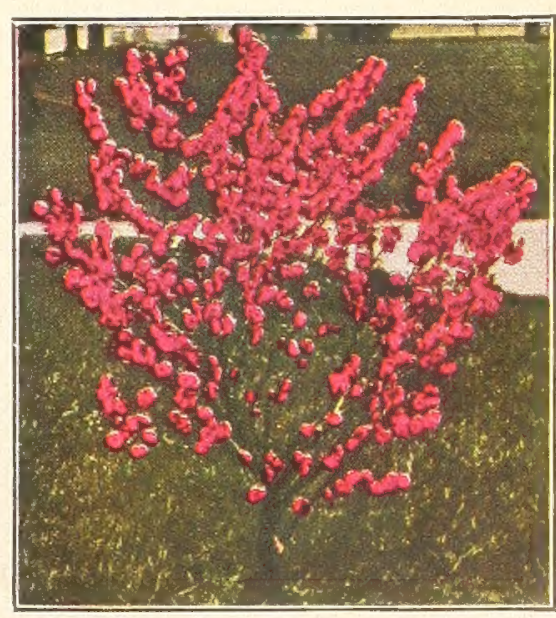

DOUBLE RED FLOWERING PEACH 


\section{PLANT NOW! HEDCES Becantiful living fences}

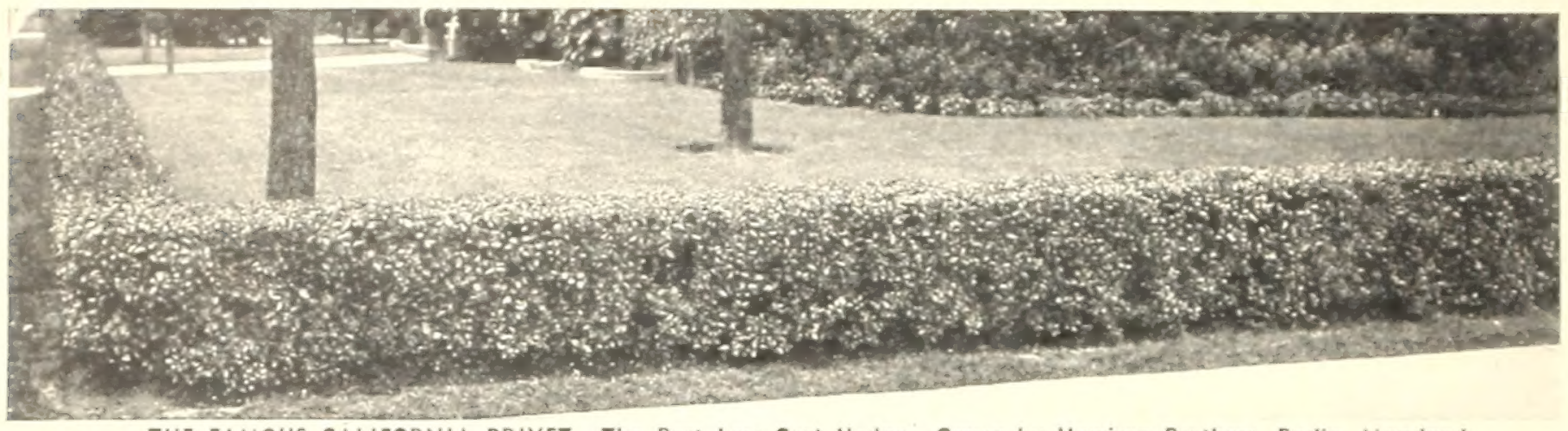

Strong, Hordy, WellRooted Plants for Quick and Permanent Hedges Horrisons' Hi-Quality

THE FAMOUS CALIFORNIA PRIVET-The Best Low Cost Hedge-Grown by Harrison Brothers, Berlin, Maryland

Grown

\section{California Privet is the Leading Low Cost Hedge Plant}

\section{CALIFORNIA PRIVET}

Ligustrum ovalifolium

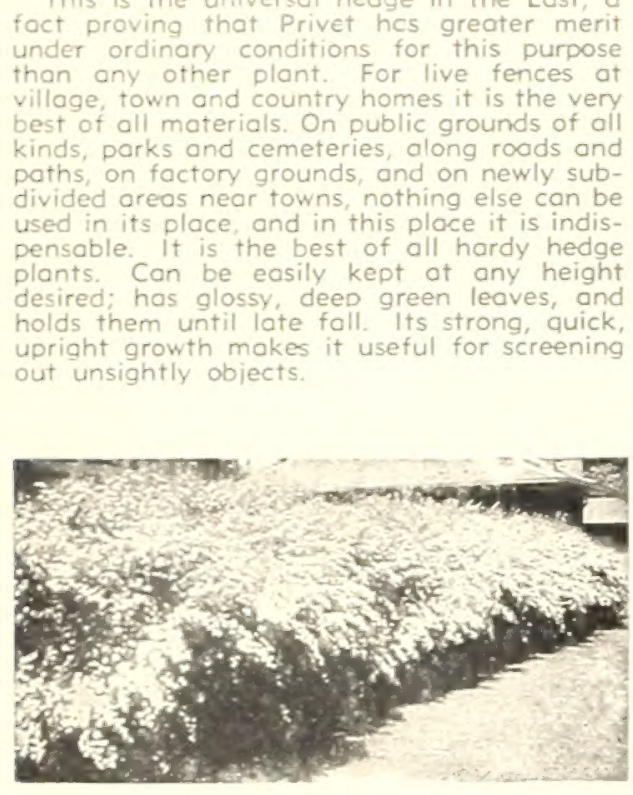

SPIRAEA YAN HOUTTEI

Alwoys Makes on Attractive Hedge

GREEN BARBERRY Berberis Thunbergi)

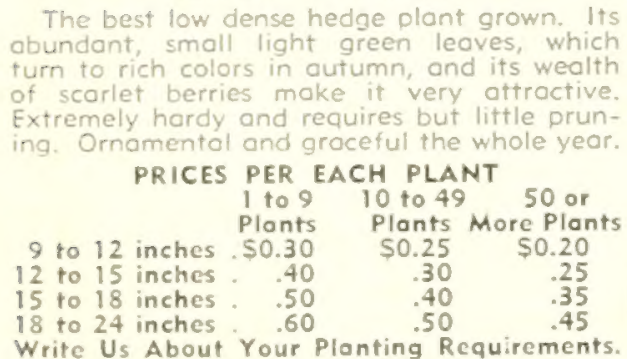

\section{A BARGAIN IN CALIFORNIA PRIVET}

We Grow California Privet by the Mile

$\begin{array}{ccc}1 \text { to } 9 & 10 \text { to } 49 & 50 \text { or } \\ \text { Plants } & \text { Plants } & \text { More Plants } \\ \$ 0.20 & \$ 0.14 & \$ 0.10 \\ .25 & .18 & .14 \\ .35 & .25 & .18 \\ .45 & .35 & .25 \\ \text { Your Planting Requirements }\end{array}$

$-4 \mathrm{ft}$.

Write Us About Your Planting Requirements.

SPIRAEA VAN HOUTTEI

grand shrub hos done more to beov-

eromes of Americo than to beau-

groups, in border plonting and for hedges.

with white flowers in April or early Moy. It

partial shode. Disease resistant, hardy,

height 6 to 8 feet but can be kept lower by

on extro fine supply of first class plants this

18 to 24 inches $\quad \begin{array}{lll}\text { Each } & 3 & 10 \\ \$ 0.70 & \$ 1.95 & \$ 6.00\end{array}$

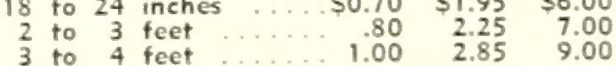

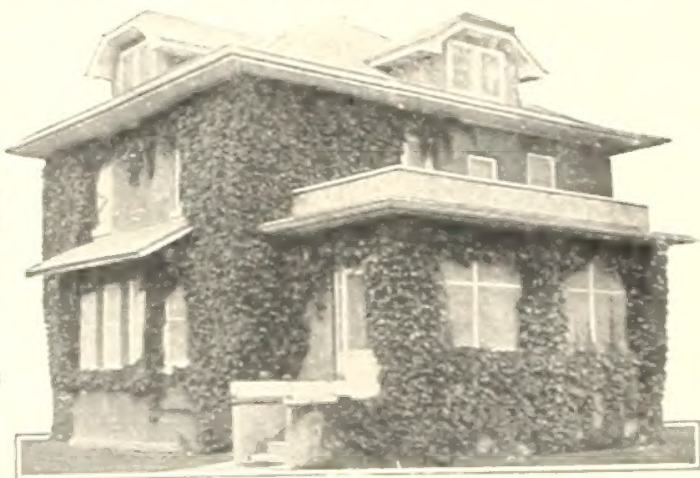

RED-LEAVED BARBERRY

Berberis Thunbergi Atropurpurea A highiy important introduction among shrubs, tinctly red foliage. This must prove a boon to all types of landscaping, where studied contrasts are 1 to 910 to 4950 or 12 to 15 inches...\$ \$0.45 $\$ 0.40 \quad \$ 0.30$ 15 to 18 inches $\quad .50 \quad 50 \quad .40$

\section{Harrisans' HARDY VINES}

NATURE'S DRAPERIES

BOSTON or JAPANESE IVY (Ampelopsis Veitchi).

stone or other material; deep, glossy green, ivyPrice: $\$ 1.00$ eoch.

CHINESE WISTARIA. A rampant growing, clingduring May and June. Price: $\$ 1.25$ eoch.

ENGLISH IVY (Hedero Hetix). The most popula evergreen vine; large, deep green, glossy folioge locations. Price: $\$ 1.00$ eoch.

HALL'S HONEYSUCKLE. Deep glossy green foli$\$ 1.00$ each.

SWEET AUTUMN CLEMATIS Clematis poniculata). A splendid climber for covering porches and trellises. Flowers snowy white, produced in outumn. Price: $\$ 1.00$ each.

SILVER LACE VINE (Polygonum Auberti). Will,

acy misty white shot with tints of cream and Price: \$1.25 each.

ENGLISH IVY-EYergreen

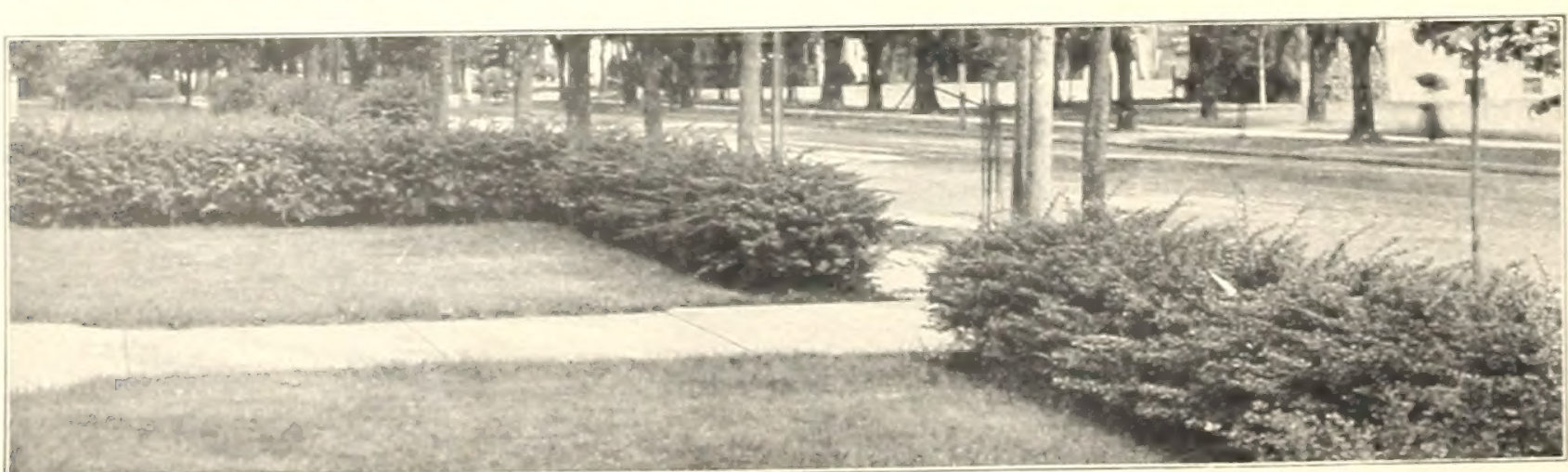

GREEN BARBERRY-Green in the summer, turning to a brilliont coppery red in late foll. A protection against small animals, becouse of the shorp thorns.

\section{BUY DIRECT FROM GROWER}

HARRISON BROTHERS, BERLIN MARYLAND

Better Plants for Less Money 

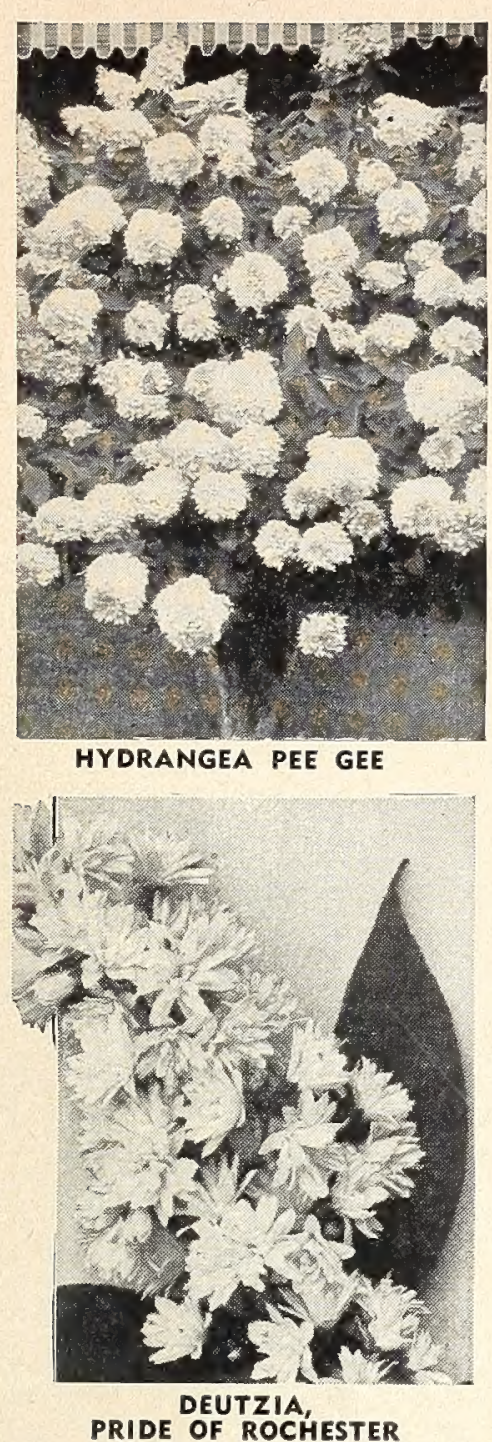

Harrisons'

\section{Lifetime Shrubs To Beautify Your Home}

\section{The Glorious Spirea Van Houttei}
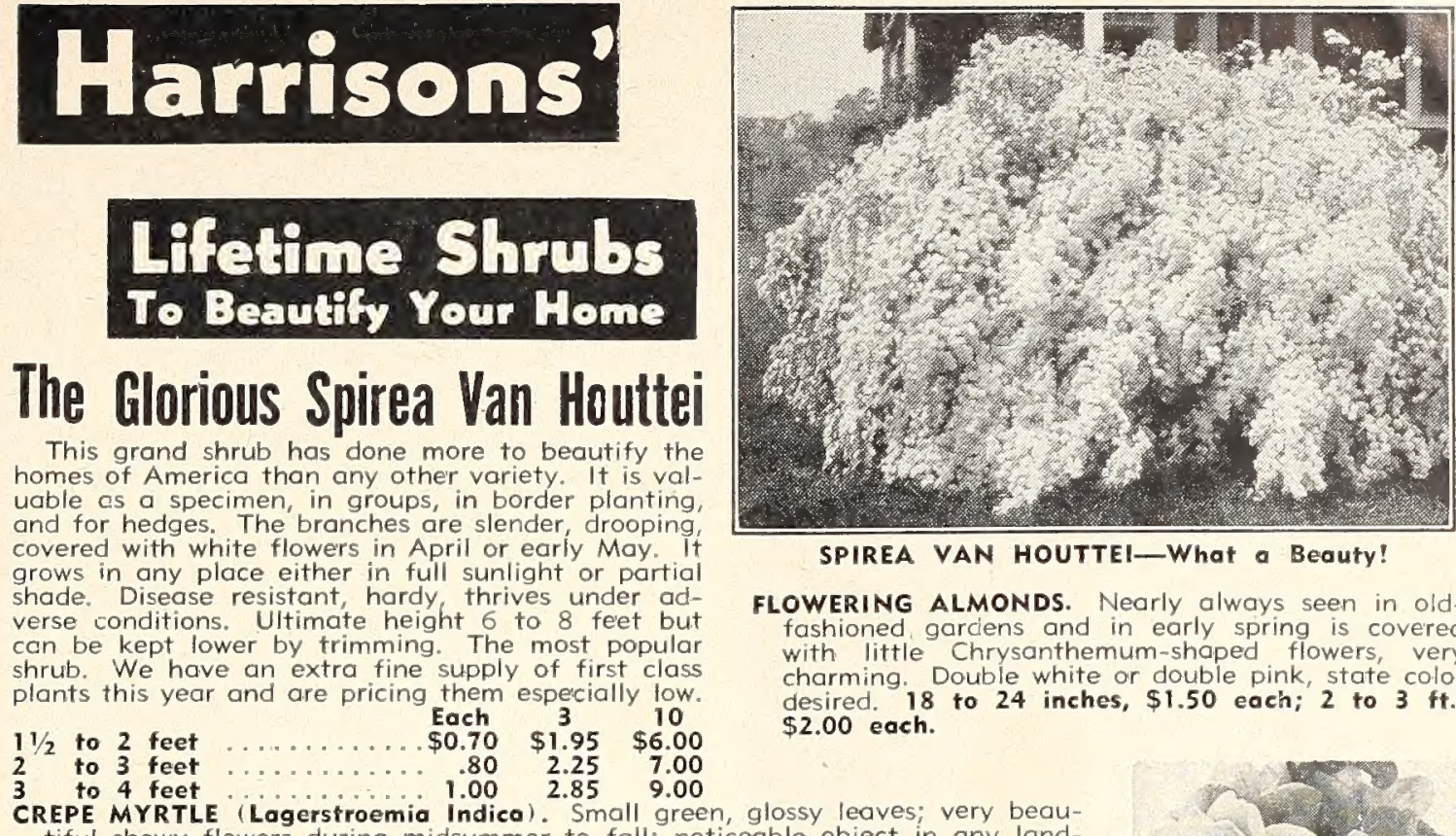

SPIREA VAN HOUTTEI-What a Beouty!

FLOWERING ALMONDS.

wath little charming, Double white or double pink, state color $\$ 2.00$ each.

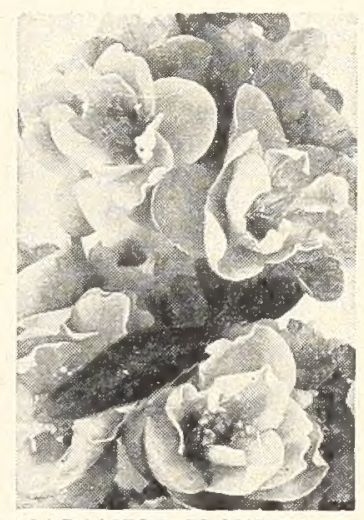

JAPANESE FLOWERING QUINCE

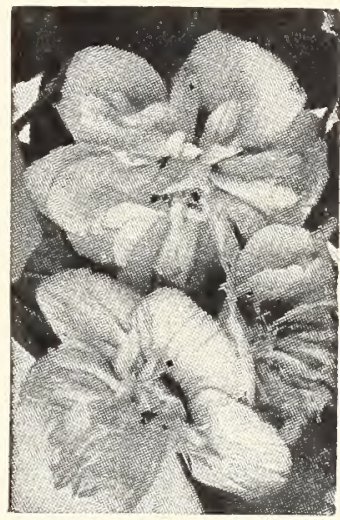

ALTHEA (Rose of Sharon)
Each 3 for

$\$ 0.70 \$ 1.95$

$.80 \quad 2.25$

$1.00 \quad 2.85$
RINGA, SWEET MOCK ORANGE or GARLAND (Phila WEET-SCENTED SHRUB (Calycanthus Floridus

$$
\begin{aligned}
& \text { hative with many double, chocolate-colo } \\
& \text { May. Flowers, leaves and wood have a }
\end{aligned}
$$

ARTARIAN HONEYSUCKLE (Lonicera Tatarica Rlossom producing an gbundance of flow

EIGELA, PINK (Weigela Rosea
ALTHEA or ROSE OF SHARON (Hibiscus Syriacus). The double and single flowers are formed in varying colors.

We can supply dout

BUDDLEIA MAGNIFICA.

est of all the summer-flowering Butterfly tedy the finbright lavender panicles. Flowers do not sunburn as do other varieties. Foliage heavy rich dark green. Very DEUTZIA, PRIDE OF ROCHESTER. Double white flowers, DOGWOD RED-BRANCHED (Cormus Albo Bright red bark, white flowers, blue fruit; rapid grower;

profusion of yellow flowers in April. One of the best HONEYSUCKLE,

flowers in June, followed by red borrowi

\section{CUSTOMER AND BANK REFERENCE}

For customer references - we refer you to any fruit grower in America who has planted Harrison-Grown fruit trees any time durFor bank references Trust Company of Maryland, BaltiExchange and Savings Bank, Berlin, Maryland; also Dun and BradYOU CAN PLACE YOUR ORDER WITH US WITH COMPLETE CONFIDENCE. It is our earnest desire that each and every one of our customers be fully satisfied in their dealings with us. If you are not and feel that it is our fault in any way please write to us. No transaction is complete unless you are completely satisfied

\section{Terms-Net Cash}

D.

We will ship C. O. D. provided a deposit of one-fourth amount of All nursery stock priced f. o. b. Berlin, Maryland.

\section{Money Back}

In the event that any nursery stock sold by us should prove untrue to name under which it is so!d, we hereby agree, on proper proof of such untrueness to name, to replace the original order or spect to all nursery stock sold by us, we give no warranty, express or implied, as to description, quality, productiveness or any other matter. HARRISONS' NURSERIES, Harrison Brothers, Props.

Note: Any money overpaid by customer will be promptly refunded.

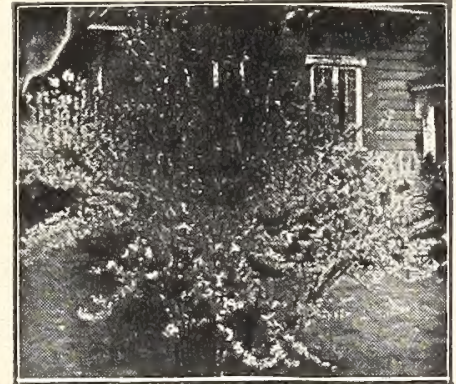

GOLOEN BELL (Forsyihia)

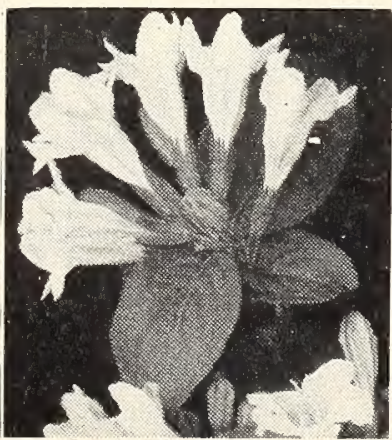

PINK WEIGELA

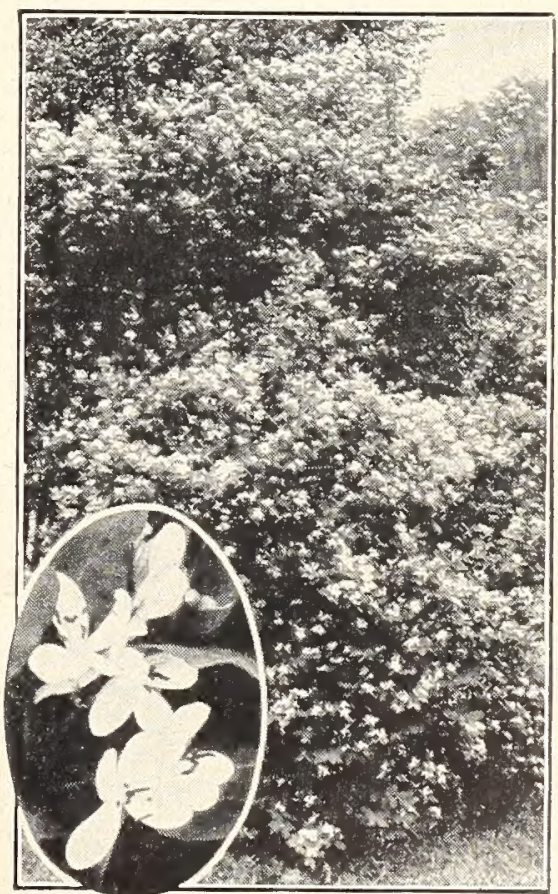

TARTARIAN HONEYSUCKLE 


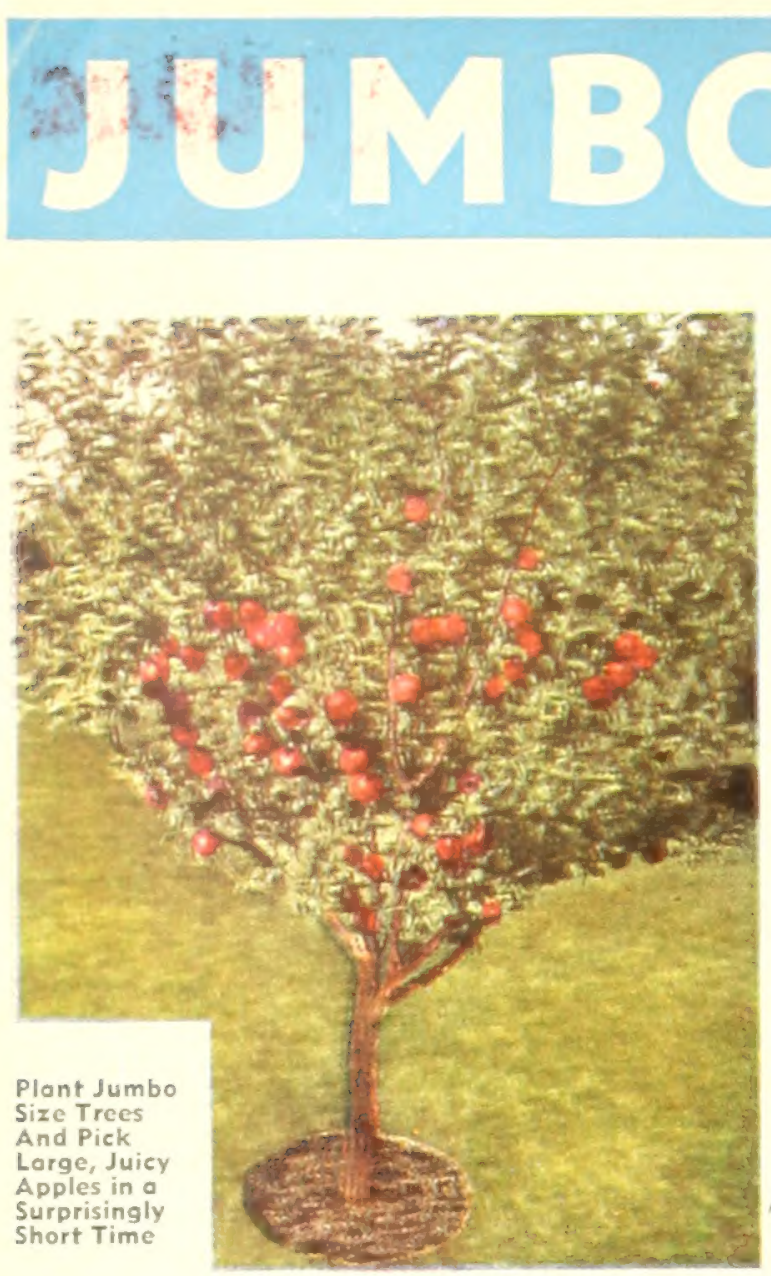

PLANT THE BEST

SAVE TWO TO THREE YEARS BY PLANTING SUPER-SIZE FRUIT TREES HAVING JUMBO GROWTH

\section{Carefully Selected Specimen Trees}

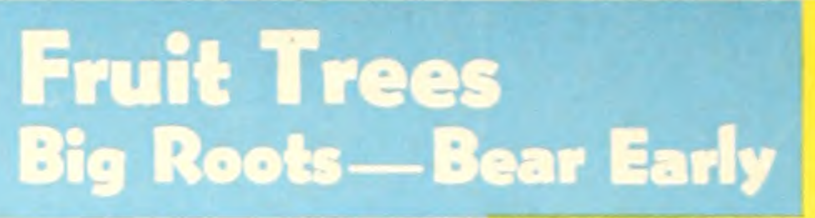

Best

Trees

\title{
OBTAINABLE -
}

NOW, Eueryane can grom extra large, rich calared, extra rich flauared, healthful VITAMIN PACKED FRUIT in yaur amn lack yard SAVE TWO TO THREE YEARS BY PLANTING SUPER-SIZE FRUIT TREES HAVING JUMBO GROWTH

Best Trees Obtainable - Carefully Selected - Specimen Trees

\author{
ALL VARIETIES LISTED IN ORDER OF RIPENING
}

\section{APPLES. Lorge Tronsporent (LLdi), Willioms Early Red, Summer}

Red Mclntosh, Triple Red Delicious, Mclntosh Red, Bright Red Jonathon, Stark
Delicious, Grimes Golden, Hyslop Crab, Yellow Delicious, Scarlet Red Stayman,
Red Yorking, Red Spy, Solid Red Winesap, Double Red Boldwin, Red Rome
Beouty, Stayman. Winesop, Rhode Islond Greening, Mammoth Block. Twig.
Prices: Jumbo Sizc, 6 to $7 \mathrm{ft}_{\text {, }}$ heavily branched Apple trees, $\$ 3.00$ eoch; 3 for $\$ 8.70$;
6 for $\$ 16.50 ; 10$ for $\$ 25.00 ; 25$ for $\$ 58.75 ; 50$ for $\$ 100.00 ; 100$ for $\$ 175.00$.

PEACHES. R.

Hole-Haven, Golden

(U.S. Plont

Prices: Jumbo Size, 6 to $7 \mathrm{tt}$. heavily bronched Peach trees, $\$ 3.00$ each; 3 for $\$ 8.70$;

Prices: Jumbo Size, 6 to $7 \mathrm{ft}$, heoyily bronched Pear trees, $\$ 3.75$ each; 3 for $\$ 10.95$ 6 for $\$ 21.00 ; 10$ for $\$ 32.50$

PLUMS. Red June, Abundance, Burbank, Santa Rosa, Methley, Satsuma,

Prices: Jumbo Size, 6 to $7 \mathrm{ft}$., hcovily branched Plum trees, $\$ 3.75$ each; 3 for $\$ 10.95$ 6 tor $\$ 21.00$; 10 for $\$ 32.50$.

CHERRIES. Black Tart

Prices: Jumbo Size, 5 to $7 \mathrm{ft}$., branched Cherry trees, $\$ 3.75$ each; 3 for $\$ 10.95$ APRICOTS.

Prices: Jumbo Size, 6 to 7 t heorily branched Apricot trees, $\$ 3.75$ eoch; 3 for $\$ 10.95$ 6 for $\$ 21.00$; 10 for $\$ 32.50$.

NECTARINES.

Prices: Jumbo Size, 6 to 7 ft heavily branched Nectorine trees, $\$ 3.75$ coch; 3 for $\$ 10.95 ; 6$ for $\$ 21.00 ; 10$ for $\$ 32.50$.

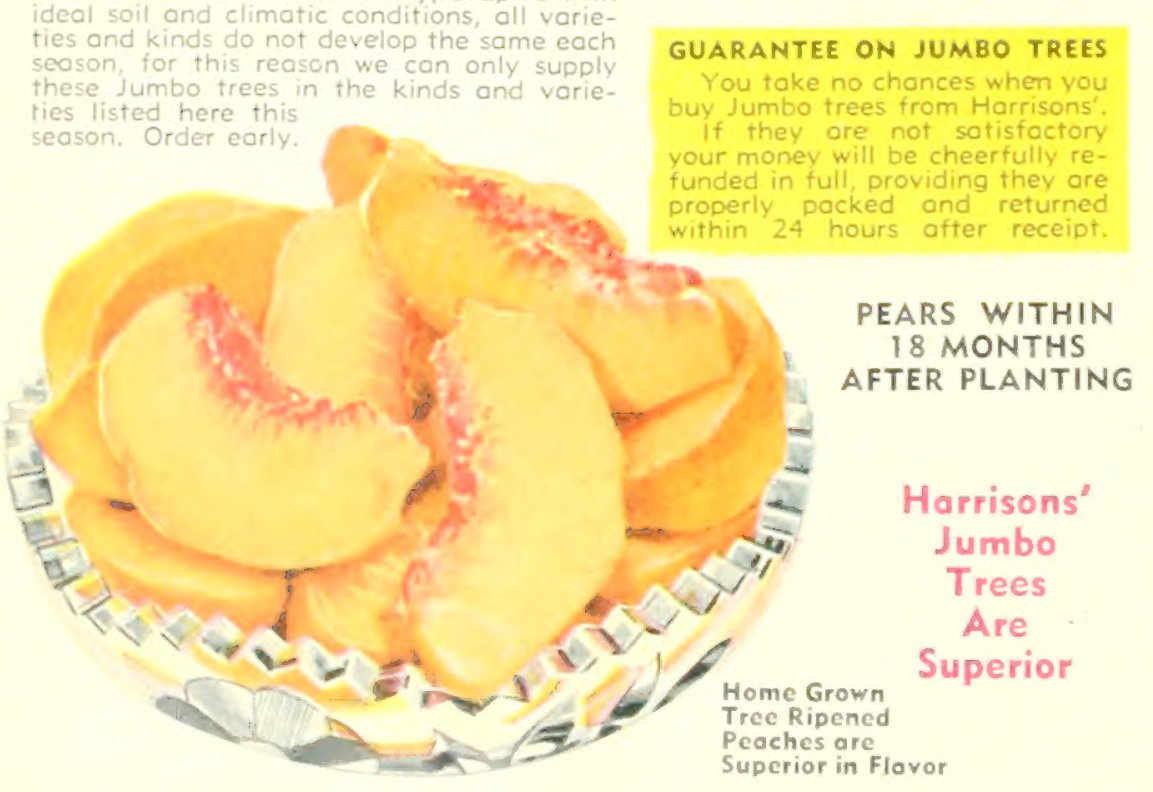

HARRISON BROTHERS NURSERIES BERLIN, MARYLAND

A NAME IN TREES YOU CAN TRUST

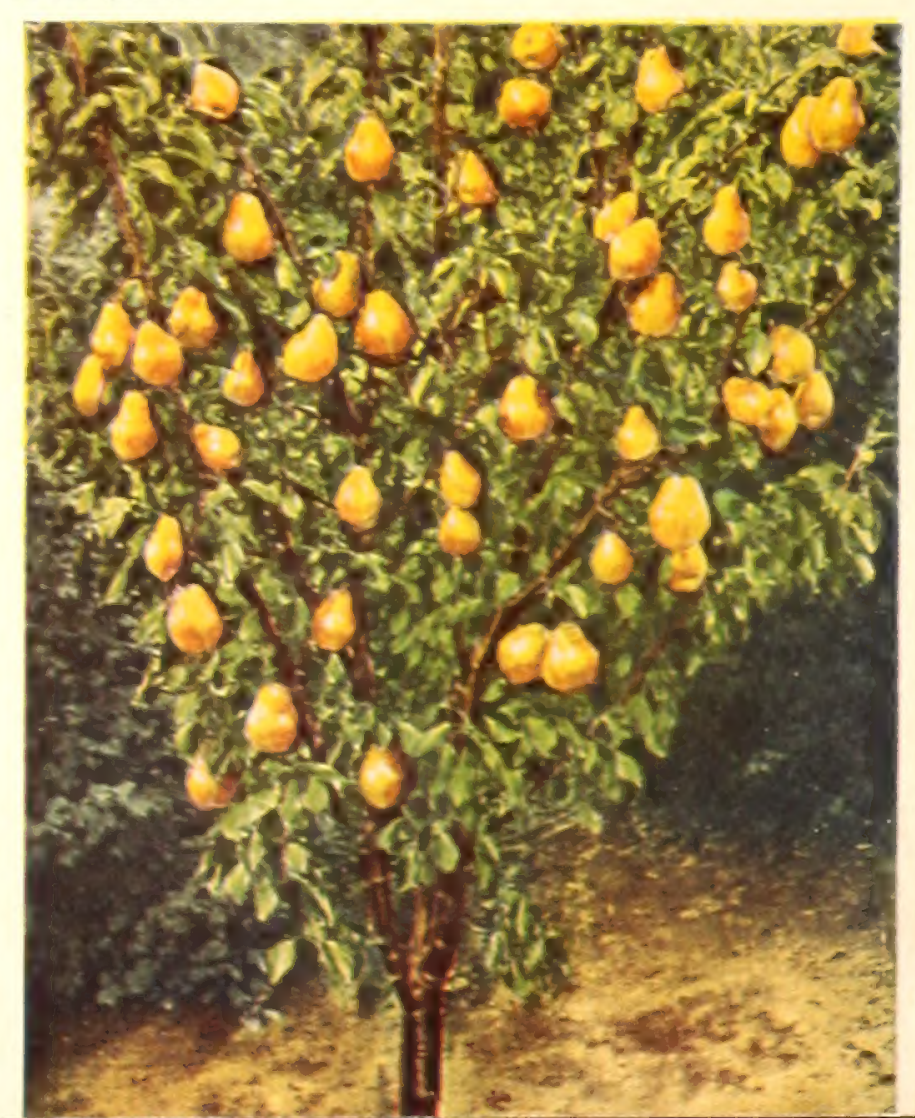

